\title{
The Semantic Principles underlying Saint Thomas Aquinas's Metaphysics of Being
}

\author{
GYULA KLIMA \\ Department of Philosophy \\ University of Notre Dame and \\ Institute of Philosophy of the Hungarian Academy
}

\section{INTRODUCTION: SEMANTICS AND METAPHYSICS}

As I hope the title clearly indicates, this article is not intended to contribute its ounces to the tons of literature on Aquinas's metaphysics of being. On the contrary, its primary motivation is the perhaps deplorable, but certainly not negligible, fact that the very form of discourse within which the substantive claims of that literature, as well as Aquinas's own claims, are formulated is radically different from that of contemporary philosophical discussions. ${ }^{1}$

Research for this paper was completed during my Morse Fellowship, which exempted me from teaching duties at the Philosophy Department of Yale University in the academic year 1994-95. I thank Desmond Paul Henry, John Jenkins, Heikki Kirjavainen, Eleonore Stump, and Jack Zupko, who read and commented on earlier drafts of this article. I also thank my new colleagues at the University of Notre Dame for a very lively and thorough discussion of the same material during my first visit here. My special thanks go to Scott MacDonald for his detailed and perceptive comments, as well as for his general suggestions for improving the presentation of the material. My original plan was to provide a nontechnical exposition of the semantic principles underlying Aquinas's metaphysics of being and goodness. I had to realize, however, both that if I do not want to compromise precision I cannot completely abandon technicalities (though I tried to relegate them mostly to the footnotes) and that the further considerations that link the notion of being to the notion of goodness would already exceed the limits of a single research paper. A full account of these further considerations, as well as the technicalities only outlined here, will be provided in my book under preparation: Meaning, Nature, Concept. Nevertheless, I do hope that the foregoing considerations will already prove useful in interpreting the passage that most clearly relates the notion of being to the notion of goodness, while also explains the difference of their predication simpliciter and secundum quid: ST1 q. 5, a. 1.

1. For pregnant expressions of the keen awareness of isolation in many contemporary Thomists, see the numerous essays devoted to this problem in D. W. Hudson and D. W. Moran, eds., The Future of Thomism, American Maritain Association Publications (Notre Dame, Ind.: University of Notre Dame Press, 1992). Of course, one cannot ignore the tremendous amount of good work done by philoso- 
Faced with this different form of discourse, modern readers are either willing (and able) to "join in," in which case they may become "players" of the relevant "language game," or they are unwilling (or unable) to do so, in which case they will be left ultimately "intellectually intact" by these claims. In either case, without careful reflection on the general principles governing "the game," this willingness (and ability) on the part of the modern reader will be determined mostly by vague intuitions and more or less articulated sympathies or antipathies, rather than by serious philosophical considerations.

As we know, metaphysics studies the first principles of all knowledge. ${ }^{2}$ But even the metaphysical investigation of first principles presupposes that we understand what is meant by these principles and their terms; that is, even metaphysical principles presuppose certain semantic principles. As Aristotle advises in the fourth book of the Metaphysics, in all disputations about first principles, the ultimate appeal should be to what both we and our opponents mean, indeed, to what both of us should mean by our phrases if we are to maintain mutual understanding in the framework of rational discourse. ${ }^{3}$ However, such an appeal is far from compelling or even unam-

phers, apparently also of some analytic background (e.g., Bochenski, Henry, Geach, Kenny, Kretzmann, McInerny, Stump, Veatch, Weidemann, just to name a few, without aiming at completeness), to overcome this "language barrier." However, as far as I know, no comprehensive attempt has been made to date to state those formal semantic principles, which as such, regardless of the metaphysical contents of their particular instances, by reason of their formality, constitute the very form of discourse presupposed in Aquinas's (and I would add, also his contemporaries') metaphysical discussions. I hope the statement and discussion of these principles below will also shed some more light on exactly how I conceive of the separation of metaphysical from formal semantic principles.

2. For this point, which of course does not define the proper subject matter of metaphysics but is a consequence of the fact that metaphysics is the study of being qua being, see In meta. lb. 4, lc. 5 . References to Aristotle are given by referring to Aquinas's commentaries. For St. Thomas's works I used the supplemental volumes to R. Busa (ed.), Index Thomisticus, S. Thomae Aquinatis Opera Omnia (Stuttgart-Bad Cannstatt: Frommann-Holzboog, 1980).

3. Cf. In meta. lb. 4, lc. 7. It is important to realize in this connection that the main thrust of Aristotle's arguments is that those who deny the first principle (i.e., the principle of noncontradiction) cannot possibly mean what they say. It is also important in this regard to consider what Aristotle and St. Thomas, in his commentary on the Posterior Analytics (hereafter PA) and in several other places, say about the order of questions to be answered by a demonstrative science. The question of what a thing is (quid est?) is preceded by the question of whether the thing is (an est?), but even this question presupposes that we know what is meant by the name of the thing in question (quid significatur per nomen). Cf. "antequam sciatur de aliquo an sit, non potest sciri proprie de eo quid est: non entium enim non sunt definitiones. Unde quaestio, an est, praecedit quaestionem, quid est. Sed non potest ostendi de aliquo an sit, nisi prius intelligatur quid significatur per nomen. Propter quod etiam Philosophus in iv Metaphysicae, in disputatione contra negantes principia docet incipere a significatione nominum" (In PA lb. 1, lc. 2, n. 5). For the significance of this order in the proofs for God's existence, see $S T 1$, q. 2, a. 2; $S c G$ lb. 1, c. 12. 
biguous, especially today, after the "linguistic turn" in philosophy, when everyone seems to have his or her own "philosophy of language" and "theory of meaning and/or reference." 4 The primary aim of this article, therefore, is to spell out with clarity and precision the underlying semantic principles of the very form of discourse presupposed by Aquinas's substantive metaphysical claims concerning being, clearly distinguishing the former from the latter. I hope thereby to ensure that the contemporary reader's willingness (and ability) to participate in the language game of competently evaluating the substantive metaphysical arguments for and against the relevant metaphysical claims will depend not on unexamined intuitions but rather on a careful consideration of these underlying principles themselves.

To be sure, in this article I cannot undertake a presentation of these underlying semantic principles as ones that we absolutely have to accept; I shall try merely to articulate as clearly as possible what it is that we have to accept for a competent evaluation of the substantive metaphysical arguments. However, of course, even within the framework of this more modest enterprise, I will have to show that these semantic principles are at least acceptable, that is, that they are consistent in themselves and do not commit anyone willing to maintain them to some manifest falsity or nonsense.

In the next section, therefore, I will begin the discussion with the introduction of the basic concepts we need for the clear formulation of the relevant semantic principles. I start with Aquinas's concept of meaning, or-using a transliteration of medieval terminology to distinguish it from contemporary conceptions-signification. However, as we shall see, there are difficulties even at the very beginning, for Aquinas's Aristotelian concept of signification apparently commits him to some "mysterious," nonexistent objects of signification. So in section III I point out how Aquinas's distinctions between different senses of 'being' might be used to eliminate our misgivings concerning such objects. ${ }^{5}$ However, this solution will leave us with a set of further, rather disturbing questions concerning the conceptual apparatus used in this discussion. So in section IV I provide a systematic account of this conceptual apparatus as it functions in Aquinas's theory of signification and predication, addressing various ontological and epistemological concerns contemporary philosophers may have regarding these semantic theories. Having thus placed Aquinas's notions of signification

4. Cf. "the double indexical definition of meaning" provided by William Lycan: "meaning $={ }_{\mathrm{df}}$ whatever aspect of linguistic activity happens to interest me now"; quoted by M. Devitt, "The Methodology of Naturalistic Semantics," Journal of Philosophy, 91 (1994): 545-72, at 548.

5. Fregean connotations aside, throughout this article, by a sense of an analogical term I simply mean one of its several but related significations. The clarification of the notion of "signification," however, is one of the tasks of the subsequent discussion. 
and existence into their proper theoretical context, in section V I finish the introduction of the basic conceptual apparatus by a brief discussion of Aquinas's account of the relationship between the signification and reference, or-again using the transliteration of medieval terminology-supposition of concrete, as well as of abstract, common terms. ${ }^{6}$ Section VI will present the formulation of the relevant semantic principles themselves, providing a brief comment on each. On this basis, in section VII I shall show how we can interpret in this framework all predications about substance as predications of some act of being either absolutely (simpliciter) or with qualification (secundum quid). Finally, in section VIII I shall argue that in this theoretical setting the metaphysical idea of an objective hierarchy of being not only makes good sense but also is even quite plausible, even if we may not be able to determine offhand the exact place of any given entity in this overall hierarchy.

\section{SIGNIFICATION AND EXISTENCE}

As is well known, what set the stage for all semantic considerations in the Middle Ages was Aristotle's "semantic triangle," the conception sketched at the beginning of his On Interpretation. According to this conception, words immediately signify the concepts of the mind, and it is by the mediation of these concepts that they signify things. Aquinas comments on the relevant passage as follows:

Therefore 'passions of the soul' must be understood here as conceptions of the intellect, and names, verbs, and speech signify these conceptions of the intellect immediately according to the teaching of Aristotle. They cannot immediately signify things, as is clear from the mode of signifying, for the name 'man' signifies human nature in abstraction from singulars; hence it is impossible that it immediately signify a singular man. The Platonists for this reason held that it signified the separated idea of man. But because in Aristotle's teaching man in the abstract does not really subsist, but is only in the mind, it was necessary for Aristotle to say that vocal sounds signify the conceptions of the intellect immediately and things by means of them. ${ }^{7}$

6. Thus, in this article I am not going to deal per se with the medieval theory of supposition in general or Aquinas's version of it in particular. I am going to touch on Aquinas's (and his contemporaries') conception of the relationship between signification and supposition only to the extent that an account of this relationship is needed for understanding Aquinas's treatment of the notion of being. Cf. n. 54 below.

7. Aristotle: On Interpretation: Commentary by St. Thomas and Cajetan, trans. J. T. Oesterle (Milwaukee: Marquette University Press, 1962), p. 25. Unless otherwise indicated (as I have done here), translations in this article are mine. 
So signification is dependent on acts of human thought: by our words we signify whatever we can think of, whether it actually exists or not. For there is no doubt that we can think of something that does not exist, and so in this conception, it follows that our words can also signify something that does not exist. Thus it is no wonder that at another place Aquinas writes as follows:

In response we have to say that there is a three-fold diversity among things signified by names. For some are in total, complete being outside the soul; and such are complete beings, such as a man or a stone. Some have nothing outside the soul, such as dreams or the imagination of a chimera. And some have some foundation in reality outside the soul, but their formal account [ratio] is completed by the operation of the soul, as is clear in the case of universals. For humanity is something in reality, but there it is not universal, for there is no humanity outside the soul common to many. But as it is conceived by the intellect, a further concept [intentio] is adjoined to it by the intellect's operation, on account of which it is called a species. ${ }^{8}$

However, this conception of signification immediately gives rise to a swarm of rather disturbing questions. For even granting that we can think of and thus speak about these mysterious, nonexistent objects of signification, the first question that immediately arises is this: what, then, are these objects that we are thus speaking about, if they are none of the things in the world? And, in any case, how exactly is our ability to signify these objects by our words related to our ability to speak about, that is, to refer to, them? What is Aquinas's conception of the relationship between meaning (signification) and reference (supposition)? Also, what can we make of Aquinas's threefold distinction among objects of signification? If chimeras and humanity as such are equally nonexistent, whatever they are in themselves, what is that 'foundation in reality' the having or lacking of which is supposed to distinguish them from one another? And, after all, what does this whole tangled issue of nonexistent objects of signification have to do with Aquinas's metaphysics of being, the semantic principles of which we are elucidating here?

\section{ENS REALE VS. ENS RATIONIS AS ENS SIMPLICITER VS. ENS SECUNDUM QUID}

Given the possibility of signifying objects of thought that do not exist (on the basis of their thinkability and the relationship between thought and signification), it is natural to ask about the nature of, and the relationships between, the members of the resulting classifications. In fact, Aquinas's famous (Aristotelian) distinctions of the various senses of 'being', which 
serve as the semantic foundation of his metaphysics of being, are part of the response to such questions.

The primary distinction concerns the notions of what in the scholastic tradition came to be known as real beings (entia realia) and beings of reason (entia rationis). Many shorter characterizations are scattered throughout Aquinas's works, ${ }^{9}$ but the fullest account of this distinction is provided by the following passage:

By way of answer we have to say that the Philosopher shows that 'being' is predicated in many ways. For in one sense 'being' is predicated as it is divided by the ten genera. And in this sense 'being' signifies something existing in the nature of things, whether it is a substance, such as a man, or an accident, such as a color. In another sense 'being' signifies the truth of a proposition; as when it is said that an affirmation is true when it signifies to be what is, and a negation is true when it signifies not to be what is not; and this 'being' signifies composition produced by the judgment-forming intellect. So whatever is said to be a being in the first sense is a being also in the second sense: for whatever has natural existence in the nature of things can be signified to be by an affirmative proposition, e.g. when it is said that a color is, or a man is. But not everything which is a being in the second sense is a being also in the first sense: for of a privation, such as blindness, we can form an affirmative proposition, saying: 'Blindness is'; but blindness is not something in the nature of things, but it is rather a removal of a being: and so even privations and negations are said to be beings in the second sense, but not in the first. And 'being' is predicated in different manners according to these two senses: for taken in the first sense it is a substantial predicate, and it pertains to the question 'What is it?' [quid est?], but taken in the second sense it is an accidental predicate . . . and it pertains to the question 'Is there [such and such a thing]?' [an est?].10

This distinction derives primarily from Aristotle's discussion of the concept of being in the fifth book of his Metaphysics, where St. Thomas starts his comments on the relevant passages with the following remarks:

[Aristotle] first divides being that is outside the soul, which is perfect being, by the ten categories. Secondly he considers another mode of

9. Cf. $2 S N$ d. 34 , q. 1 , a. $1 ; 1 S N$ d. 19 , q. 5, a. 1 , ad 1, d. 33, q. 1, a. 1 , ad 1.; $2 S N$ d. 37, q. 1, a. 2, ad 1 and 3; De ente c. 1; QDP q. 7, a. 2, ad 1; QDM q. 1, a. 1, ad 19.; QDL 9, q. 2, a. 2; In meta. lb. 4, lc. 1, lb. 5, lc. 9, lb. 6, lc. 2, lb. 6, lc. 4, lb. 9, lc. 11, lb. 11, lc. 8; $S T 1$ q. 3, a. 4, ad 2, q. 16, a. 3, ad 2, q. 48, a. 2, ad 2; $S T 1$ 2, q. 36, a. 1; ScG lb. 1, c. 12, lb. 1, c. 58, lb. 3, c. 9, lb 3, c. 8, n. 13. Cf. also T. de Vio Cajetan, Commentary on Being and Essence, trans. L. J. Kendzierski and F. C. Wade (Milwaukee: Marquette University Press, 1964), c. 1; C. Alamannus, Summa Philosophiae (Paris: P. Lethielleux, 1888), Tom.1. sect. 2, 5, 1; R. W. Schmidt, The Domain of Logic according to Saint Thomas Aquinas (The Hague: Martinus Nijhoff, 1966), part 2, chap. 4, and part 3 , chap. 8 .

10. $2 S N$ d. 34 , q. 1 , a. 1 . 
being, according to which it is only in the mind. . . Thirdly he divides being by potentiality and actuality: and being thus divided is more common than perfect being. For a being in potentiality is only a being with qualification [secundum quid] and is imperfect. ${ }^{11}$

But the same distinction is considered even earlier by St. Thomas, in his comments on book 4 of the Metaphysics, where he embeds this distinction into the broader context of his famous doctrine of the analogy of being. ${ }^{12}$ Having discussed the ways in which the various analogous senses of 'healthy' (according to which it can be predicated even of food and of urine) are related to one another, namely, the various ways in which its secondary senses are related to its primary sense (which signifies the health of an animal), Aquinas says that 'being' is analogous in the same way in that all of its secondary senses are related to a primary sense, namely, the sense in which 'being' is predicated of substance. He summarizes his discussion in the following passage:

We should know that the above-mentioned modes of being can be reduced to four. For one of them, which is the weakest, is only in reason, namely, negation and privation, which we say are in reason because reason considers them as if they were some beings, when it affirms or denies something of them. . . Another [mode of being], which is the closest to this one in weakness, is that according to which generation and corruption and motions are said to be beings. For they have some privation and negation mixed with them. For motion is imperfect actuality, as is said in book 3 of the Physics. [A being] in the third sense has nothing of non-being mixed with it, but it has a weak existence [habet esse debile], for [it has existence] not by itself, but in something else, as [do] qualities, quantities and properties of sub-

\section{In meta. lb. 5 , lc. 9 .}

12. Of course, Aquinas's doctrine of analogy in general is in itself a huge and hotly debated topic. Nevertheless, the details of that doctrine, describing exactly how the various analogous senses of an analogous term are related to one another and to the things named analogously, need not be considered here. As we shall see below, all we need in the present context is to realize that a secondary sense of an analogous term may be expressed by adding some diminishing qualification to the same term in its primary sense, that is, that a secondary sense of an analogous term is the result of some modification of the primary sense. However, we need not consider in detail exactly how such modifications can occur; that is, we need not consider what are the different modes of analogy, which is the focus of the debates. For a masterly exposition of the issues involved, see R. McInerny, The Logic of Analogy (The Hague: Martinus Nijhoff, 1961). Recently Professor McInerny has also kindly given me the opportunity to consult the manuscript of his new book under preparation (Aquinas and Analogy), which presents a detailed, although also debatable, criticism of Cajetan's interpretation of analogy. Cf. also E. J. Ashworth, "Analogical Concepts: The Fourteenth-Century Background to Cajetan," Dialogue, 31 (1992): 399, and "Analogy and Equivocation in Thirteenth-century Logic: Aquinas in Context," Mediaeval Studies 54 (1992): 94. 
stance. The fourth kind is that which is the most perfect, namely, that which has existence in nature without any admixture of privation, and has firm and solid existence, as it exists by itself, as do substances. And it is to this [last one], as primary and principal, that all the others are related. For qualities and quantities are said to be insofar as they are in a substance; motions and generations are said to be insofar as they tend to substance or to some other of the above-said [beings]; and privations and negations are said to be insofar as they remove some of the above-said three. ${ }^{13}$

Thus, as we can see, the distinction between ens reale and ens rationis is regarded by St. Thomas as forming part of the division of the common term ens, that is, 'being', into its various, though related, analogical senses. Concerning this kind of division in general, as opposed to the division of a genus into its species, St. Thomas writes the following:

There are two ways in which something common can be divided into what are under it, just as there are two ways in which something is common. For there is the division of a univocal [term] into its species by differences by which the nature of the genus is equally participated in the species, as animal is divided into man and horse, and the like. Another division is that of something common by analogy, which is predicated according to its perfect concept [ratio] of one of those that divide it, and of the other[s] imperfectly and with qualification [secundum quid], as being is divided into substance and accident, and into being in actuality and in potentiality. ${ }^{14}$

Accordingly, however obscure the details of the divisions of the notion of being may appear at first, the first thing to realize about the distinction between real beings and beings of reason is that it does not constitute a division of a class into its subclasses as, for example, the distinction between rational and nonrational animals constitutes the division of the class of animals into two kinds of animals, namely, humans and brutes. Real beings and beings of reason do not in the same way constitute two subclasses or two kinds of beings. Indeed, they no more constitute two kinds of beings than real money and forged money constitute two kinds of money. Just as it is only real money that is money simpliciter, that is, without qualification, so it is only a real being that is a being simpliciter, without qualification. As medieval logicians (and Aquinas himself) would say, the qualification 'of reason' as added to 'being' or 'forged' as added to 'money' is an example of a "diminishing" qualification or determination (determinatio diminuens), whereas the qualification 'real' in both cases is a "nondiminishing" qualification (determinatio non diminuens). The origin of the theory of these two kinds of determination goes back to Aristotle's Sophistical Refutations, in

13. In meta. lb. 4, lc. 1, n. 15 .

14. In Peri lb. 2, lc. 2, n. 3. 
particular to his treatment of the fallacy referred to by the schoolmen as the fallacy secundum quid et simpliciter. ${ }^{15}$

According to the medieval analysis, the fallacy consists in dropping a diminishing qualification in an inference from a proposition in which a predicate is applied to a subject with some qualification (secundum quid) to a proposition in which the same predicate is applied to the same subject absolutely, without qualification (simpliciter). In his De Fallaciis, ${ }^{16}$ Aquinas characterizes this fallacy in the following manner:

Next, about the fallacy secundum quid et simpliciter. In this context, that is [said to be] predicated simpliciter which is predicated without any modification [ modus] added to it, as when we say: 'Socrates is white' or 'Socrates runs'; and that is [said to be] predicated secundum quid which is predicated with the addition of something to it, as in 'He runs well' or 'Socrates is white with respect to his teeth'. What is added may be related in two ways to that to which it is added: for sometimes it does not diminish the concept [ratio] of that to which it is added, and then it is possible to proceed from what is secundum quid to what is simpliciter, as when we say: 'He runs fast; therefore, he runs', for speed does not take away anything from the concept $[$ ratio $]$ of running. . . . Sometimes, however, what is added takes away something from the concept [ratio] of that to which it is added, as when it is said: 'A black man is white with respect to his teeth'. For the qualification 'with respect to his teeth' takes something away from the concept of what is said to be white, since nobody can be said to be white, except who is totally white, or with respect to most or the principal parts. Therefore, if someone were to conclude: 'A black man is white with respect to his teeth; therefore, he is white', then this is a sophistic argument, or an instance of the fallacy secundum quid et simpliciter, and the deception derives from taking what is predicated secundum quid as if it were predicated simpliciter. ${ }^{17}$

Thus, when the qualification is diminishing, its omission yields an invalid inference. But when it is nondiminishing, that is, when the qualification added to the predicate does not specify any conditions for the applicability of the predicate other than those included in the meaning of the predicate in itself, then its omission preserves the truth of the original proposition. As Aquinas explains somewhat later, when discussing the several modes in which this fallacy can occur,

15. For a more comprehensive discussion of, and further references to, the medieval literature on this fallacy (in connection with St. Thomas's use of the related theoretical apparatus in his theology of the Incarnation), see G. Klima, "Libellus pro Sapiente: A Criticism of Allan Bäck's Argument against St. Thomas Aquinas' Theory of the Incarnation,” The New Scholasticism, 58 (1984): 207-19.

16. A minor work whose authenticity recently has been vindicated. See Father Busa's note at the end of the list of works included in the supplements (very conveniently printed at the end of each volume) of his monumental Index Thomisticus.

17. De Fallaciis c. 13. 
We should know, however, that if a whole is aptly denominated from its part, then there is no fallacy, as is clear in this case: 'He is curly with respect to his hair; therefore, he is curly'. This correctly follows, for a man is denominated curly with respect to his hair. And this mode covers also other [sorts of] parts, namely, [parts] of place, of time, or of other [sorts of] wholes. If, however, something is added to a whole in place by the mediation of a part in place, from which part it is not aptly denominated, the fallacy occurs in such inferences, as [in the following]: 'This diet is good in unhealthy places, so it is good'. This does not follow, for 'in unhealthy places' signifies a part in place. The case is similar with a whole and part in time, as here: 'Drinking wine is bad for the sick; therefore, it is bad'. And the same goes for all similar cases. ${ }^{18}$

Therefore, on the one hand, since 'real' as added to 'being' is a nondiminishing qualification, a real being is simply a being. On the other hand, since 'of reason' as added to 'being' is a diminishing qualification, a 'being of reason' is not necessarily a being, except secundum quid. ${ }^{19}$ But then we can see that our question about the nature of nonexistent objects of signification (at the end of the previous section) was based on a category mistake. For the question about the nature of anything presupposes that it has a nature. But this, again, presupposes that it exists, that is, that it is a being simpliciter, a real being:

Since there is no quiddity or essence of a non-being, nobody can know, with regard to that which is not, what it is; but one can know the signification of the name, or the description composed of several names; as for example one can know what the name 'tragelaphus' (or 'goatstag', which is the same thing) signifies since it signifies an animal composed of a goat and a stag. But it is impossible to know what a goatstag is, for nothing is like this in the nature of things. ${ }^{20}$

Therefore, to ask, 'What are nonexistent beings of reason?', where that question is understood as asking about the nature of a curious kind of being, namely, beings that do not exist, is just as misguided as asking about the actual currency exchange rate between, say, yen and forged dollars. But again, this does not mean that we cannot understand what we mean by the phrase 'beings of reason'. On the contrary, as just explained, such beings

\section{De Fallaciis c. 13.}

19. Cf. "Unum enim eodem modo dicitur aliquid sicut et ens; unde sicut ipsum non ens, non quidem simpliciter, sed secundum quid, idest secundum rationem, ut patet in 4o Metaphysicae, ita etiam negatio est unum secundum quid, scilicet secundum rationem" (In Peri lb. 2, lc. 2, n. 3).

20. In PA lb. 2, lc. 6, n. 2. Cf. In PA lb. 1, lc. 2, n. 5: " antequam sciatur de aliquo an sit, non potest sciri proprie de eo quid est: non entium enim non sunt definitiones. Unde quaestio, an est, praecedit quaestionem, quid est. Sed non potest ostendi de aliquo an sit, nisi prius intelligatur quid significatur per nomen. Propter quod etiam Philosophus in iv Metaphysicae, in disputatione contra negantes principia docet incipere a significatione nominum." 
of reason are what certain expressions signify in virtue of the fact that we can think of them when we understand the expressions in question, whether they actually exist in rerum natura or not.

So far, so good. But even if this response dulls somewhat the critical edge of this disturbing question, I hardly think any contemporary philosopher would be absolutely satisfied by the explanations given so far, and apparently for good reasons. For were not these explanations just a series of obscura per obscuriora, vain attempts to elucidate some obscure distinctions by other, even more obscure ones? After all, we started out at the end of the previous section by answering our disturbing questions about the distinction between existent and nonexistent objects of signification by presenting St. Thomas's quite obscure distinction between the two senses of 'being'. This turned out to be just a part of a more comprehensive distinction among the various analogous senses of the same word. In its turn, the explanation of this latter distinction led to further distinctions, namely, those between predication simpliciter and predication secundum quid and between determinatio diminuens and determinatio non-diminuens - and all of this just to pave the way for dismissing one of our initial questions as mistaken. Thus, the dubious result of eliminating this question by this procedure was achieved at the expense of introducing distinctions that are bound to give rise to even further and even more disturbing questions. For how are we supposed to understand St. Thomas's claims in his distinction of the two notions of being? Why would blindness be a nonbeing or a being only in the second sense? And even if it is, why would this rather obscure fact be expressed by the copula of an affirmative proposition? And what should we make of the claim that the concept of being that is applicable to blindness is a result of somehow "diminishing" the concept of being that is applicable to sight, which is in turn a concept of being that results from another "diminishing" of the concept of being that is applicable to substances, that is, to ordinary things such as animals that can be sighted or blind? Indeed, what does the fact that an animal is sighted or blind have to do with the existence (in any sense) of such spurious entities as blindness or sight?

\section{SIGNIFICATION AND THE INHERENCE THEORY OF PREDICATION}

To provide acceptable replies to these questions as well as to the previous ones, we have to start with a systematic account of Aquinas's conception of signification. As we have seen, for Aquinas our words have two sorts of signification, immediate and ultimate. What a word immediately signifies is a human concept, the possession and actual exercise of which makes a human being aware of something.

Note here that by this claim Aquinas is not committed to any particular "philosophy of mind and language" (although, of course, he has one) or to 
any particular psychological or psycholinguistic theory. For such theories would certainly have to have an answer to the question of what human concepts in themselves are. That is, they would have to characterize the nature of these acts of human awareness and the nature of their relationship to their subject, the human mind, which in turn would demand a characterization of the nature of the human mind itself, and so forth. Aquinas's claim in itself, however, determines nothing concerning such issues. Instead, it merely introduces a certain terminology for speaking in a fairly general fashion about things familiar to anyone. For of course anyone who speaks any language at all is familiar with the fact that the intelligent use and understanding of a meaningful word necessarily involves the ability to think or be aware of what the word is used for by the users of that language, that is, the ability to think or be aware of what other users of the same language think or are aware of when they use the word with understanding. It is only the same familiar fact that is expressed otherwise by saying that words-certain meaningful utterances or inscriptions of a language-immediately signify concepts of the users of the language. That is, they are meaningful to users of the language precisely because they are conventionally attached to concepts-certain acts of human awareness or understanding - of the users of the language. To know this much, however, we do not have to know what thinking or awareness or understanding is or what these acts of awareness or concepts are. Whatever it is that accounts for a human being's ability to think of what a word is used for in a linguistic community, that is, whatever it is that accounts for a human being's ability to use a meaningful word with understanding-be it a brain process, a spiritual modification, or whatever else a philosopher can think up-that is what we call here a concept immediately signified by the word in question. Thus, whatever it is that makes me (or you) aware of human beings in general when I (or you) use the word 'man' in English (say, in the sentence 'I'm looking for a good man'), that is what is here called the concept of human beings signified immediately by the word 'man' in the minds of those who understand English (or at least this much of English).

Of course, by saying that words immediately signify concepts of the human mind Aquinas was not claiming that words are simply the signs of these concepts. Words are ultimately the signs of the objects of these concepts; that is, (categorematic) words signify ultimately what the concepts they immediately signify make us aware of. ${ }^{21}$ It is a concept of this

21. Of course, syncategorematic terms do not have such ultimate significata in themselves, as their function is not to signify but only to cosignify (consignificare). See n. 68 of E. J. Ashworth, "Signification and Modes of Signifying in ThirteenthCentury Logic: A Preface to Aquinas on Analogy," Medieval Philosophy and Theology 1 (1991): 39-67. For a formal treatment of syncategorematic terms along these lines, see Essay V of G. Klima, Ars Artium: Essays in Philosophical Semantics, Medieval and Modern (Budapest: Institute of Philosophy of the Hungarian Academy of Sciences, 1988), but we are not concerned here with syncategorematic terms. 
sort that St. Thomas calls the ratio of the things it makes us aware of. But, perhaps curiously to the modern reader, according to St. Thomas this ratio is not only in the intellect but somehow also in the thing thought of:

The ratio of any thing is what its name signifies, as the ratio of a stone is what its name signifies. But names are the signs of intellectual conceptions, whence the ratio of any thing signified by a name is the conception of the intellect that the name signifies. And this conception of the intellect is in the intellect as in its subject, but it is in the thing thought of as in that which is represented: for the conceptions of the intellect are certain similitudes of the things thought of. But if the conception of the intellect were not assimilated to the thing, then the conception would be false of that thing; for example, if the intellect would think something that is not a stone to be a stone. So the ratio of the stone is in the intellect as in its subject, but it is in the stone as in that which causes truth in the conception of the intellect thinking the stone to be such and such. ${ }^{22}$

In another passage, discussing how the attributes we predicate of God may apply to him, Aquinas explains in more detail in what sense we can say that the ratio is in the thing:

We should know that a ratio, as taken here, is nothing else, but what the intellect apprehends from the signification of some name, and this in the case of those things that have definition is the definition of the thing itself, in accordance with what the Philosopher says: 'the ratio signified by the name is the definition'.23

But some things, which are not defined, are [also] said to have a ratio in this way, e.g., things such as quantity or quality, which are not defined because they are most general genera. Nevertheless, the ratio of quality is what is signified by the name of quality; and it is that from which quality has it that it is quality. Thus it makes no difference whether those things that are said to have a ratio have a definition. And so it is clear that the ratio of wisdom predicated of God is what is conceived of in the signification of this name, even if divine wisdom itself cannot be defined. Nevertheless, the name 'ratio' does not signify this conception itself, because that is signified by the name of wisdom, or by some other name of the thing, but it signifies the intention of this conception, just as the name 'definition' does and other names of second imposition do. And thus the second point, namely, the one concerning how the ratio is said to be in the thing, is also clear. For this does not mean that

22. Resp. ad lect. Vercell. de art. 108, q. 1. Cf. "Ratio enim quam significat nomen, est conceptio intellectus de re significata per nomen" (ST1 q. 13, a. 4).

23. In meta. lb. 4, lc. 16, n. 733. 
the intention itself which is signified by the name 'ratio'would be in the thing, nor even that the conception to which this intention applies would be in the thing outside the soul, for it is in the soul as in its subject; but it is said to be in the thing insofar as there is something in the thing outside the soul that corresponds to the conception of the soul, as what is signified [corresponds] to the sign. ${ }^{24}$

There are two points in this passage that must be clearly understood for the subsequent discussion. The first is that the name 'ratio' is a name of second imposition. The second is that to know the ratio of a thing, and hence the meaning of its name, we need not know the essential definition of whatever is conceived of in that ratio. That is, we can clearly know what a name signifies without knowing what the thing signified by the name is in itself. 25

24. $1 S N$ d. 2, q. 1, a. 3. in corpore

25. Or, using medieval terminology, we can know the quid nominis without knowing the quid rei. The distinction itself is most aptly characterized by Aquinas's famous commentator, Cajetan, in the following way:

Just as the quid rei is the thing's quiddity, so the quid nominis is the quiddity of the name: but a name, as it is the sign of the passions that are objectively in the soul (from bk. 1. of Aristotle's Perihermeneias), does not have any other quiddity but this, namely, that it is a sign of a thing understood or thought of. But a sign, as such, is relative to what is signified: so to know the quid nominis is nothing, but to know what the name, as a sign, is related to, as what is signified. Such a knowledge, however, can be acquired by the accidental properties of what is signified, as well as by its common, or by its essential properties, or simply by a gesture, or whatever else you like. For example, if we ask a Greek about the meaning of anthropos, if he points to a man, at once we know the quid nominis, and similarly in other cases. But to those asking about the quid rei, it is necessary to give what belongs to the thing adequately, in the first mode of perseity [i.e., in virtue of its essence-for the four modes of "perseity," i.e., of predication per se; see In PA lb. 1, lc. 10]. This is the essential difference between the quid nominis and the quid rei: namely, that the quid nominis is the relation of the name to what it signifies; but the quid rei is the essence of the thing related or signified. And from this difference follow all the rest that are usually enumerated: namely, that the quid nominis is of nonentities, complexes, by accidental, common, and external properties; while the quid rei is of incomplex entities [grasped] by their proper, essential properties. For a word's relation can be terminated to non-existents, and complexes, and it can be clarified by accidental and similar properties, but the thing's essence can be known only by proper, essential properties of incomplex things. [Sicut quid rei est quidditas rei, ita quid nominis est quidditas nominis: nomen autem, cum sit nota earum quae sunt obiective in anima passionum (ex primo Perihermeneias), non habet aliam quidditatem nisi hanc, quod est signum alicuius rei intellectae seu cogitatae. Signum autem ut sic, relativum est ad signatum: unde cognoscere quid nominis nihil est aliud, quam cognoscere ad quid tale nomen habet 
As to the first point, we should know that St. Thomas applies a common medieval distinction here, roughly comparable to the contemporary distinction between expressions of an object language and expressions of a metalanguage. However, for the medievals this distinction did not concern two languages distinct and complete in themselves, one of which is designed to speak about things other than its own expressions, the other of which is designed to speak about the expressions of the former. On the contrary, here we have expressions of the same language distinguished with respect to their function in speaking about different types of objects, namely, about either concepts or the objects of these concepts. As we have seen, for Aquinas a word is meaningful because it immediately signifies some concept of the human mind. But the word is imposed to signify ultimately the object of this concept, that is, what the actual exercise of this concept makes a human being aware of. Some concepts, however, make us aware not of objects of external reality, but of concepts of the mind. So just as, say, the concept that makes us aware of human beings in general is the concept of human beings, so the concept that makes us aware, say, of concepts that make us aware of things that differ only numerically but not by essential differences (as does the concept of human beings or the concept of horses or the concept of oak trees) is the concept of species. On the other hand, concepts that have as their objects things other than concepts are called first intentions (intentiones primae), and, correspondingly, their names are called names of first imposition (nomina primae impositionis). On the one hand, concepts that have concepts as such as their objects are called second intentions (intentiones secundae), and, correspondingly, their names are called names of second imposition (nomina secundae impositionis).

The qualification 'as such' is needed here because there are concepts that have both concepts and things other than concepts as their

\begin{abstract}
relationem ut signum ad signatum. Talis autem cognitio potest acquiri per accidentalia illius signati, per communia, per essentialia, per nutus, et quibusvis aliis modis. Sicut a Graeco quaerentibus nobis quid nominis anthropos, si digito ostendatur homo iam percipimus quid nominis, et similiter de aliis. Interrogantibus vero quid rei oportet assignare id quod convenit rei significatae in primo modo perseitatis adaequate. Et haec est essentialis differentia inter quid nominis et quid rei, scilicet quod quid nominis est relatio nominis ad signatum; quid rei vero est rei relatae seu significatae essentia. Et ex hac differentia sequuntur omnes aliae quae dici solent: puta quod quid nominis sit non entium, complexorum, per accidentalia, per communia, per extranea; quid rei vero est entium incomplexorum per propria et essentialia. Relatio enim vocis potest terminari ad non entia in rerum natura, et complexa, et declarari per accidentalia et huiusmodi, essentia autem rei non nisi per propria essentialia habetur de entibus incomplexis.]
\end{abstract}

T. de Vio Cajetanus, "Super Librum De Ente et Essentia Sancti Thomae," in Opuscula Omnia (Bergomi, It.:Typis Comini Venturae, 1590), p. 299. 
objects. For example, the concepts of 'being', 'thing', and the like are clearly of this sort. Still, these concepts are not second intentions since, even if they do represent concepts as well as other things, they do not represent concepts qua concepts-that is, qua acts (whatever they are in themselves) that make humans aware of something-but qua beings or qua things in their own right (regardless of whatever their function in human cognition may be). Indeed, even if there were intentions that have only concepts as their objects but do not represent them qua concepts, those intentions would not be second intentions. For example, even if it turned out that what are here called concepts are brain processes, this stunning discovery would not turn the concept of a brain process into a second intention, for it does not characterize whatever makes a human aware of something in terms of the relationship of this act of awareness to the object of this act but otherwise, as some natural phenomenon in its own right, certain bioelectric changes in a particular sort of grayish stuff. 26

However, the concept of species, for example, as interpreted by the medievals, is a concept of a concept qua concept because it characterizes or represents concepts as such, that is, in their function of making humans aware of certain sorts of things in a particular manner. ${ }^{27}$ In the same way, as Aquinas explains in the passage quoted above, the concept of ratio is a second intention, and hence its name is a name of second imposition because it represents concepts of other things qua concepts, that is, insofar as these concepts are related to their objects, naturally representing them in a certain manner. Hence, what the name 'ratio' immediately signifies is the intention of ratio, a second intention, which represents concepts in their function in human cognition. But in that case the intention of ratio applies to concepts that represent their own objects, and hence the name 'ratio' refers to these concepts.

As Aquinas goes on to explain, however, we can also say that the ratio is in the thing. But this is not intended in the sense that the concept by which the thing is conceived of would be in the thing, for the concept is in

26. This is basically what accounts for the futility of all reductionist attempts to explain away talk about mental acts in terms of a purely physicalistic language, regardless of whether what we speak about as mental acts are in fact only brain processes, that is, modifications of matter, or something else, distinct from such material modifications.

27. In any case, this is how Aquinas, along with many other medieval authors, would interpret the standard Porphyrean definition: "species est praedicabile in quid de pluribus solo numero differentibus," insofar as the relation of predicability of many things is what definitively characterizes a universal as such, whereas a universal as such is nothing but an abstract, universal concept which, again, as such, is an act of human awareness that makes humans aware of the nature of particulars in abstraction from the individuating conditions with which it only can exist in particulars. Cf. De ente c. 4. 
the human mind as in its subject. ${ }^{28}$ What this means is that there is something in the thing corresponding to the ratio-what Aquinas calls the form or nature of the thing-on account of which the concept applies to this thing at all. ${ }^{29}$ For example, if the concept in question is a universal concept of many particulars, as the concept of man ${ }^{30}$ is a specific concept that represents humans in abstraction from their accidental, individuating features, then the ratio in the mind is this concept itself. But the ratio in the thing is what is represented by this concept in the thing, and that is what is referred to as human nature, or humanity, on account of which the thing represented is a human being. Indeed, what accounts for the intellect's ability to think of humans in this manner is its capacity to think or be aware of humans precisely qua humans, that is, to be aware of them only with respect to what makes them humans, their human nature, disregarding whatever other features they may have, such as color, gender, weight, height, virtues or vices, and so on. It is precisely this capacity, the capacity to abstract the natures or forms of things from their individualizing conditions, that accounts for the very possibility of humans' ability to have universal concepts. As St. Thomas explains,

\begin{abstract}
When we speak about an abstract universal, we imply two things, namely the nature of the thing itself, and abstraction or universality. So the nature itself to which it is accidental that it is thought of, or that it is abstracted, or that the intention of universality applies to it, exists only in the singulars, but the nature's being abstracted or its being thought of or the intention of universality is in the intellect. And we can see this by the similar situation in perception. For sight sees the color of an apple without its smell. Thus, if it is asked: Where is the color that is seen without the smell?-it is obvious that it is nowhere else, but in the apple. But that it is perceived without the smell happens to apply to it [accidit ei] on account of sight, insofar as in sight there is a similitude of color but not of smell. Similarly, humanity that is thought of exists only in this or in that man; but that humanity is
\end{abstract}

28. For a discussion and formal semantic reconstruction of the details of Aquinas's rather intricate doctrine of concepts (which, again, we need not consider here), especially with respect to their relationships to their subjects, to their objects, and to what St. Thomas calls natura absolute considerata, see G. Klima, "'Socrates est species': Logic, Metaphysics and Psychology in St. Thomas Aquinas's Treatment of a Paralogism," in Argumentationstheorie: Scholastische Forschungen zu den logischen und semantischen Regeln korrekten Folgerns, ed. K. Jacobi (Leiden, Neth.: Brill, 1993), pp. 489-504.

29. This is why the form of the thing that corresponds to the concept, or ratio, of the mind is also called a ratio: "Forma vero quae et ratio nominatur, quia ex ipsa sumitur ratio speciei, dicitur substantia quasi ens aliquid actu, et quasi ens separabile secundum rationem a materia." (In meta. lb. 8, lc. 1, n. 1678).

30. In the sense of human being-in general, the medieval concept of homo, as signifying the species of humans, was not regarded as gender specific. 
apprehended without its individuating conditions (which is nothing but for it to be being abstracted, which confers on it the attribute of universality) is an accidental feature of humanity [accidit humanitati] in virtue of its being perceived by the intellect, in which there is a similitude of the nature of the species but not of the individuating principles. ${ }^{31}$

But then, concerning the second point mentioned above, we should clearly realize that even if by having such a concept in our minds we necessarily are aware of human nature without its individuating conditions, this does not mean that we necessarily have to be able to say what this human nature is. For to have this concept means only to be able to think or to be aware of humans in this abstract and hence universal manner. But the ability to think of humans in this way is nothing but the ability to think of humans only qua humans, only in terms of what it is necessary for something to have if it is to be a human (regardless of any other features it may have); and this is precisely what is called a human nature, or a humanity, namely, what makes the thing in question a human being, regardless of whether we are able to spell out what this nature is in terms of other concepts by providing an essential definition of human beings. Therefore, by having this concept of human beings we are necessarily aware of human nature as such, in abstraction from its individualizing conditions in particular humans, whether we are able to give any other characterization of this nature in terms of other concepts or not. Of course, if we do know the essential definition of the thing in question, then we are also in a position to give an answer in terms of other concepts to the question that asks about the nature of the thing: we can tell what the thing is, what it is that it has to have if it is to be the kind of thing it is. But, as St. Thomas insisted in the case of divine wisdom, this is not required of us in order to have a ratio, or concept, of the thing, an act of simple apprehension by which we can be aware of the thing with respect to the form or nature represented by this ratio. Indeed, since this ability to think of particular things in this abstract, universal manner is what it is for us to have the abstract concepts, or rationes, of particular things, and since our words signify immediately our concepts (on account of which they signify ultimately what we conceive of in these concepts), it is precisely this human ability that accounts for the presence of universal terms in human languages, signifying things in the same universal manner, with respect to the natures of particular things conceived of in their concepts without their individualizing features. But since this applies to all sorts of universal terms (in all sorts of human languages), we can state in general that a universal term immediately signifies an abstract and hence universal concept of the human mind, on account of which it ultimately signifies 
whatever is conceived of by this concept in the particulars (without conceiving their individualizing features), namely, the individualized natures or forms of particulars, which render them such as to fall under this concept. For despite our ability to think of particulars in this abstract, universal manner, and hence our common terms' ability to signify them in the same way, the form or nature signified by a general term in this particular thing is, of course, a numerically distinct entity from the form or nature signified by the same term in that particular thing. As St. Thomas writes,

It is not necessary that if this is a man and that is a man, then they both have numerically the same humanity, just as two white things do not have numerically the same whiteness; but [it is necessary] that the one be similar to the other in that it has humanity just as the other: whence the intellect, considering humanity not as belonging to this thing, but as humanity, forms an intention that is common to all. ${ }^{32}$

Thus, the abstractive consideration of the intellect is able to conceive of these particular, individualized forms in a universal manner (considering, say, this whiteness or that whiteness only as whiteness but not considering this whiteness as belonging to this thing or that whiteness as belonging to that thing). It is therefore able to confer universal meaning on certain sounds and inscriptions as parts of a human language. However, it is only this humanity, say, the humanity of Socrates, or that humanity, say the humanity of Plato, or this whiteness of this white sheet of paper, or that whiteness of that white sheet of paper that exists in rerum natura. For even if, say, this whiteness or that whiteness can be considered without considering whether it belongs to this thing or to that thing, no whiteness can be without being the whiteness of this thing or of that thing, that is, without belonging to this thing or to that thing. And this is necessarily so because for this whiteness to be is nothing but for this thing to be white and vice versa, and of course it is only some particular thing that can be white. Thus, in this semantic conception, for some particular thing to be white is nothing but for its particular whiteness (the particular quality that is represented in a universal manner by the human concept that renders the term 'white' in English meaningful) to be. But then this is why, according to St. Thomas, we use the verb of existence even when we want to express only the simple fact that a thing actually is white: "Since actuality, what is principally signified by the verb 'is', is in general the actuality of all forms, whether substantial or accidental actuality, when we want to signify any form or actuality to be actually in a subject, we signify this by the verb 'is'." 33

32. 2 SN d. 17 , q. 1, a. 1 .

33. In Peri lb. 1, lc. 5, n. 22. 
Of course, this is just one of several of Aquinas's formulations of the theory of predication that historians of medieval logic duly dubbed the inherence theory. ${ }^{34}$ Stated as a general, formal semantic principle, the inherence theory claims,

(1) The predication of a common term $\mathrm{F}$ of an individual $\mathrm{u}$ is true if and only if the form ultimately signified by $\mathrm{F}$ in $\mathrm{u}$ actually $i s$, that is, exists. 35

Again, I have to stress that despite possible modern worries to the contrary, this claim, as a formal semantic claim, does not involve the introduction of any sorts of "mysterious" or spurious entities. This apparently atavistic talk about "forms" and "natures," clearly of the same breed as Molière's mocked talk about dormative powers, in this semantic interpretation need not commit us to any curious sorts of entities other than those familiar to anyone nor to any sort of epistemological nonsense, such as having to have some "metaphysical intuition" into the ordinarily hidden nature of things.

By saying that a general term ultimately signifies a form in the particulars that render those particulars such that they actually fall under the concept immediately signified by the term in question, we do not need to posit some new sorts of mysterious entities in the thing. Indeed, we need not do so here any more than we need to posit any sorts of further, mysterious entities (beyond those anyone would agree to be familiar with) when we talk about concepts in this semantic context. (Remember, talk about concepts in itself neither implies nor excludes the possibility that the acts of awareness that, in relation to their objects, we talk about as concepts are in themselves just brain processes. However, there being such acts of awareness in the intended sense is just such a familiar fact of human existence that denying their existence would yield

34. Cf., for example, L. M. de Rijk, "Introduction," to P. Abaelard, Dialectica (Assen, Neth.: 1956), pp. 37-38; D. P. Henry, Medieval Logic and Metaphysics (London: 1972), pp. 55-56; P. T. Geach, "Nominalism," God and the Soul (London: 1969).

35. Cf., for example, "Oportet enim veritatem et falsitatem, quae est in oratione vel opinione, reduci ad dispositionem rei sicut ad causam. Cum autem intellectus compositionem format, accipit duo, quorum unum se habet ut formale respectu alterius: unde accipit id ut in alio existens, propter quod praedicata tenentur formaliter. Et ideo, si talis operatio intellectus ad rem debeat reduci sicut ad causam, oportet quod in compositis substantiis ipsa compositio formae ad materiam, aut eius quod se habet per modum formae et materiae, vel etiam compositio accidentis ad subiectum, respondeat quasi fundamentum et causa veritatis, compositioni, quam intellectus interius format et exprimit voce. Sicut cum dico, Socrates est homo, veritas huius enuntiationis causatur ex compositione formae humanae ad materiam individualem, per quam Socrates est hic homo: et cum dico, homo est albus, causa veritatis est compositio albedinis ad subiectum: et similiter est in aliis" (In meta. lb. 9, lc. 11, n. 1898). 
a self-defeating claim). ${ }^{36}$ Thus, just as we could start talking about concepts without having to commit ourselves to any particular theory about what concepts in themselves are, so we can start talking about the 'forms' of things as the ultimate significata of our words without having to take a metaphysical stance about what these 'forms' in themselves are. Of course, talking about these ultimate significata as forms, rather than anything else, indicates the close historical relationship between this semantic conception and a hylomorphist metaphysics. This, however, does not mean that this semantic approach in itself logically implies a hylomorphist metaphysics in general ${ }^{37}$ or any specific version of it in particular. In fact, such an implication would leave no room for metaphysical disagreements to be disputed within the same semantic framework. But of course, many of the great metaphysical disputes of high scholasticism can be construed as revolving precisely around the distinctness (or identity) of the semantic values commonly assigned to several expressions within basically the same semantic framework.

This is most obvious in the famous debate concerning the unicity and plurality of substantial forms. Recapitulated in semantic terms, the point of the debate was to decide whether the ultimate significata of the substantial predicates of the same individual are the same or distinct. This question is left open by the semantic principles of signification and predication, but it

36. For more on this subject see the comments on rule (1) in section VI.

37. In fact, that the ultimate significata of common terms need not necessarily be regarded metaphysically as forms in all cases was a commonplace also for thinkers who otherwise were committed to a hylomorphist metaphysics. As St. Thomas wrote, "Dicendum est quod illud a quo aliquid denominatur non oportet quod sit semper forma secundum rei naturam, sed sufficit quod significetur per modum formae, grammatice loquendo. Denominatur enim homo ab actione et ab indumento, et ab aliis huiusmodi, quae realiter non sunt formae" (QDP q. 7, a. 10, ad 8). Cf. also, for example, "Verum ne fallaris cum audis denominativum a forma denominante oriri, et credas propter formae vocabulum quod res denominans debet esse forma eius quod denominatur, scito quod formae nomine in hac materia intelligimus omne illud a quo aliquid dicitur tale, sive illud sit secundum rem accidens, sive substantia, sive materia, sive forma." Thomas de Vio Cajetan, Scripta Philosophica: Commentaria in Praedicamenta Aristotelis, ed. M. H. Laurent (Rome: Angelicum, 1939), p. 18. In general, it is precisely this point that lies at the bottom of the distinction between extrinsic and intrinsic denomination. Cf. also "Nam, sicut dicit Commentator, duodecimo Metaphysicae, grammaticus videt in multis differre dispositionem et dispositum, et sic movetur ad imponendum eis nomina diversa, ut 'albedo' et 'album'; et quia non est ejus inquirere an in omnibus vel in quibus sic differant dispositio et dispositum, ipse secundum similitudinem ad illa in quibus manifeste differunt imponit etiam aliis nomina per modum dispositionis et dispositi, seu determinationis et determinabilis, vel etiam determinati, derivando ab abstracto concretum vel e converso, relinquens metaphysico considerationem an illa nomina supponant pro eodem vel pro diversis, propter quem diversum modum significandi grammaticalem illa nomina habent diversos modos praedicandi. (Jean Buridan, Lectura de Summa Logicae: De Praedicabilibus c. 7, n. 4, H. Hubien's unpublished edition). 
has far-reaching ramifications in both metaphysics and theology. ${ }^{38}$ Again, the same semantic framework leaves undetermined the question of whether the significata of such substantial predicates should be regarded as identical with or distinct from the significatum of the predicate 'is' in the same individual. Hence the need for Aquinas to deploy several metaphysical arguments for his famous thesis of the real distinction in creatures between essence and existence, that is, between the significata of substantial predicates and the significata of the verb 'is', while, of course, the same semantic principles allow him to state the identity of these significata in the case of God. ${ }^{39}$ But the same semantic principles do not determine even whether the significatum of a predicate in an individual is distinct from this individual itself. So again, anyone having ontological, that is, metaphysical qualms about "multiplying entities" is free to construe the significata of predicates with respect to the particulars as being the particulars themselves, at least as far as the semantics is concerned. ${ }^{40}$ However, of course, such a decision will again have its metaphysical consequences, so anyone wishing to do so

38. An excellent historical summary of the debate with ample further references is provided by D. A. Callus, "Forms, Unicity and Plurality of," in New Catholic Encyclopedia, Catholic University of America (New York: McGraw-Hill, 1967-79).

39. See, for example, De ente c. 5.

40. Without intending to go too much into technicalities, let me just give here a brief indication of how this claim can be made exact in a formal semantic system. If $\mathbf{P}$ is a common predicate, then the ultimate significate of $\mathrm{P}$ in respect of an individual $u$ at a time $t$ may be assigned by the semantic function SGT in a model in the following way: $\operatorname{SGT}(P)(u)(t) \in W \cup\{0\}$, where $W$ is the domain of the model, $t$ is some time, and 0 is a zero entity $(0 \notin W)$. The case $\operatorname{SGT}(P)(u)(t)$ $=0$ represents the situation that $P$ signifies nothing in $\mathrm{u}$, as, for example, the predicate 'red' signifies nothing in respect of the number 2. It is also reasonable to stipulate that SGT $(P)(0)(t)=0$. Then, if the set of things that are actual at a certain time $t, A(t)$, is a subset of $\mathrm{W}$, in accordance with the inherence theory of predication we can say that the predication of $\mathrm{P}$ of an individual $\mathrm{u}$ at a certain time $t$ in a present-tense sentence (i.e., the copula of which consignifies the time $t$ of the utterance) is true if and only if $\operatorname{SGT}(\mathrm{P})(\mathrm{u})(\mathrm{t}) \in \mathrm{A}(\mathrm{t})$. Now this much of semantics can certainly stay in place whether in a particular model SGT $(P)(u)(t)$ $=u$ or $\operatorname{SGT}(P)(u)(t) \neq u$. But the former case represents precisely the simple ontology in which the significate of $\mathrm{P}$ in $\mathrm{u}$ at $\mathrm{t}$ is not an entity distinct from $\mathrm{u}$ but is $u$ itself. In such an ontology, for example, the predicate 'round' in respect of a round thing, say, a billiard ball, would signify the ball itself, but in respect of, say, a cube, it would signify nothing (SGT ('round') (ball) $(\mathrm{t})=$ ball, SGT('round') (cube) $(\mathrm{t})=0$ ). Nevertheless, in general, I do not intend to go into technicalities here. I will only indicate in the notes how the semantic principles could be given exact formulations in a model-theoretical framework. For a complete semantic system constructed along these lines to represent St. Thomas's ontology, see G. Klima, "On Being and Essence in St. Thomas Aquinas's Metaphysics and Philosophy of Science," Knowledge and the Sciences in Medieval Philosophy: Proceedings of the Eighth International Congress of Medieval Philosophy, ed. S. Knuuttila, R.Työrinoja, and S. Ebbesen, vol. 2, series B19 (Helsinki: Luther-Agricola Society, 1990), 210-221. For the issue of the independence of this semantic construction from that particular ontology, see Essay V of my Ars Artium. 
will have to face, among others, Aquinas's metaphysical arguments to the effect that in material beings such an identification is impossible, whereas in the case of God it is more than justified. ${ }^{41}$ Finally, not only do these formal semantic principles, namely, the inherence theory of predication and the corresponding theory of signification, leave undetermined the questions of the identity or distinctness of the ultimate significata and supposita of common predicates, but they also leave undetermined the question of whether in the thing there really is in actual being something that corresponds to a predicate-an actually inherent form-even when the predicate is true of this thing. For certain predicates, namely, negative or privative predicates, which in their very concept involve the lack of what their opposite signifies, are true of something precisely because the opposite significatum is lacking in this thing. So for the former to $b e$ is for the latter not to be. But then the being of the significatum of the negative or privative predicate is nothing but the nonbeing of the significatum of the opposite positive predicate. Therefore, since nothing can be both being and nonbeing in the same sense, the significatum of the privative or negative predicate cannot be said to be in the same sense as the significatum of the opposite positive predicate. Indeed, this is precisely what seems to be the primary motivation for the Aristotelian distinction between the two senses of 'being' with which we started our discussion. As, in a different context, Aquinas writes,

As was said above, 'being' is predicated in two ways. In one way it signifies the essence of a thing existing outside of the soul; and in this way the deformity of sin cannot be said to be a being, for it is a certain privation, but privations do not have an essence in the nature of

41. See, for example, ST1 q. 3, a. 3; Quodl. 2, q. 2, a. 2[4]. However, I think it is also interesting to note here that the possibility of identifying everything with substance even in the case of material substances was considered already by a medieval philosopher, John of Mirecourt, who denied all sorts of metaphysical distinctions corresponding to semantic distinctions in rebus, even the distinction between substance and accident. In fact, it is somewhat ironical that it took an "arch-nominalist" like Jean Buridan, someone who himself reduced the number of distinct ontological categories to three (namely, to substance, quantity, and quality), to deploy several metaphysical arguments against this "obscure and dangerous" doctrine. Cf. M. M. Adams, "Things versus 'Hows,"” in How Things Are, ed. J. Bogen and J. E. McGuire (Dordrecht, Neth.: Reidel, 1985), pp. 175-88, esp. pp. 179-80. Of course, there are substantial differences between Aquinas's and Buridan's (and probably also Mirecourt's) approach to semantics. The point, however, is that for both of them, semantics does not dictate to ontology: however differently we may pick out things for our consideration, whether we do pick out distinct things or just the same thing differently is not determined by semantics, and so this has to be determined by careful metaphysical considerations. For more on this issue and the particular differences between Aquinas's and Buridan's approach to semantics, see G. Klima, "Ontological Alternatives vs. Alternative Semantics in Medieval Philosophy," in Logical Semiotics, $S$-European Journal for Semiotic Studies, 3:4 (1991): 587-618. 
things. In the second way ['being'] signifies the truth of a proposition; and in this way a deformity is said to be, not that it has being in the thing, but because the intellect compounds a privation with its subject as if it were some form. Therefore, just as from the composition of a form with a subject or with matter there results some substantial or accidental being; so does the intellect signify the composition of a privation with a subject by some being. But this being is only being of reason, for in the thing it is rather non being. ${ }^{42}$

Thus, whatever common predicate we substitute for $\mathrm{F}$ in (1) above, (1) will hold; only the sense of 'is' or 'exists' in it may vary, depending on the kind of significatum $\mathrm{F}$ has in $\mathrm{u}$. In fact, on the basis of this point one may already surmise how the different senses of 'being' distinguished by Aquinas are related to the different kinds of predicates that can occur in actual predications. However, before considering this relationship we have to consider the function of common terms in the other necessary component of an actual predication in a proposition, namely, the subject term, which supplies the referent, or suppositum, for the predication.

\section{SUPPOSITION AND SIGNIFICATION OF ABSTRACT AND CONCRETE TERMS}

So far I have been gathering and discussing Aquinas's semantic ideas concerning common terms as they are predicable of individuals. As we saw, according to this conception, a common term in an actual predication, that is, as the predicate of a categorical proposition, ultimately signifies some individualized property of the individual (or individuals) of which it is predicated, that is, of the individual (or individuals) that is (or are) referred to by the subject of the proposition. But common terms can themselves function as subjects, and then, according to medieval logicians, they also have the function to refer to (or to use the modern transliteration of medieval terminology: supposit for) the individuals that fall under them. ${ }^{43}$ In this referring function, then, despite the fact that they signify what we called the forms of the particulars (that is, their ultimate significata in the particulars, whatever those ultimate significata are in themselves), they normally refer to, or supposit for, the particulars themselves. As St. Thomas says,

In respect of any name, we have to consider two things, namely, that from which the name is imposed (which is called the quality of the

42. $2 S N$ d. 37 , q. 1 , a. 2.

43. For formal reconstructions of the relevant medieval ideas and ample references to and discussion of the enormous amount of contemporary literature they generated, see Essays II-IV of my Ars Artium. 
name) and that on which the name is imposed (which is called the substance of the name). And the name, properly speaking, is said to signify the form, or quality, from which the name is imposed, and is said to supposit for the thing on which it is imposed. ${ }^{44}$

So, for example, the term 'man' signifies human nature in abstraction from the singulars immediately and signifies individual human natures ultimately, but normally—say, in the proposition 'A man is white'-it supposits for the things that actually bear the nature it signifies, namely, individual humans..$^{45}$ But then this proposition is true if and only if the form ultimately signified by its predicate term in at least one of the supposita of the subject term actually exists, that is, if and only if the individual whiteness of at least one of the individuals that actually has humanity-the whiteness of a human being-actually exists.

44. $3 S N$ d. 6 , q. 1, a. 3. It is important to note here that although St. Thomas sometimes also contrasts $i d$ a quo with $i d$ ad quod nomen imponitur to distinguish the etymology of a name from its proper signification (the stock example being "lapis"; cf., e.g., ST1. q. 13, a. 2, ad 2. ), we must not confuse the two distinctions. As St. Thomas himself pointed out: "nomen dicitur ab aliquo imponi dupliciter: aut ex parte imponentis nomen, aut ex parte rei cui imponitur. Ex parte autem rei nomen dicitur ab illo imponi per quod completur ratio rei quam nomen significat; et haec est differentia specifica illius rei. Et hoc est quod principaliter significatur per nomen. Sed quia differentiae essentiales sunt nobis ignotae, quandoque utimur accidentibus vel effectibus loco earum, ut VII Metaphys. dicitur; et secundum hoc nominamus rem; et sic illud quod loco differentiae essentialis sumitur, est a quo imponitur nomen ex parte imponentis, sicut lapis imponitur ab effectu, qui est laedere pedem. Et hoc non oportet esse principaliter significatum per nomen, sed illud loco cuius hoc ponitur" (QDV q. 4, a. 1, ad 8). Thus, id a quo nomen lapidis imponitur, ex parte rei, is the ratio seu natura lapidis, that is, the nature of stones, sometimes also referred to as lapideitas, namely, what is signified by the term lapis, whatever it is, and whether we know it in terms of an essential definition or not; whereas id a quo nomen lapidis imponitur, ex parte imponentis, is the accidental property of stones that they tend to hurt the foot (laedere pedem), which may have provided the motivation for so naming them. (Whether Isidore of Seville's etymology is actually correct or not is irrelevant here.) For a more detailed discussion of the two distinctions and references to their earlier history, see Ashworth, "Signification," pp. 39-67, esp. pp. 47-50.

45. I say "normally" because it is only in some special context that a term is made to refer to what it normally signifies. As Aquinas says, "Quia enim forma significata per hoc nomen 'homo', idest humanitas, realiter dividitur in diversis suppositis, per se supponit pro persona; etiamsi nihil addatur quod determinet ipsum ad personam, quae est suppositum distinctum. Unitas autem sive communitas humanae naturae non est secundum rem, sed solum secundum considerationem, unde iste terminus 'homo' non supponit pro natura communi, nisi propter exigentiam alicuius additi, ut cum dicitur, 'Homo est secies'” (ST1 q. 39, a. 4; cf. ST3 q. 16, a. 7). Of course, those familiar with medieval logic will immediately recognize here a case of simple supposition, as opposed to personal supposition. However, as I said before, in this article I do not intend to go into the technicalities of supposition theory. Following Aquinas's practice, when I will speak about a term's supposita without any qualification, I will intend the term's personal supposita. 
But here we should note again that this semantic distinction between suppositum and significatum, as such, need not posit any real distinction between what is signified and what is supposited for by a common term in a proposition. Even if, according to Aquinas's metaphysical views, a real distinction corresponds to this semantic distinction in the case of material beings (and thus, for example, a human being is not his or her humanity, and a wise person is not his or her wisdom), nevertheless in the case of God there is no corresponding real distinction between what is signified and what is supposited for, although the semantic distinction is still in force (for example, the predicate 'wise' is still related to divine wisdom as to its significatum and to God as to its suppositum since, as a consequence of divine simplicity, God is identical with divine wisdom). 46 Thus, at least as far as common concrete terms are concerned, their mode of signification (modus significandi) is such that they signify their ultimate significata in particular things (whether these significata are actual or merely potential). But as subjects of categorical propositions, they supposit for those particular things in which their ultimate significata actually exist. ${ }^{47}$ Nevertheless, what they ultimately signify and what they supposit for may or may not be identical, depending on the nature of the things signified and supposited for. Thus, the question of the identity or distinction of their supposita and significata is a metaphysical question, not determined by the semantic distinction. However, the abstract counterparts of these concrete terms differ from them precisely in their mode of signification, insofar as abstract terms both signify and supposit for what their concrete counterparts signify. But they do not supposit for the supposita of their concrete counterparts, except when these supposita are identical with the significata. This is why we can refer to the significata of concrete terms by their abstract counterparts and say, for example, that the term 'man' signifies humanity (whereas it supposits for humans) and that a man is not identical with his humanity,

46. Cf. "Respondeo dicendum, quod natura et suppositum naturae in quibusdam differunt re et ratione, sicut in compositis; in quibusdam autem ratione et non re, sicut in divinis" ( $3 S N$ d. 11 , q. 1, a. 4, in corp). Cf. also "propter divinam simplicitatem, consideratur duplex realis identitas in divinis eorum quae differunt in rebus creatis. Quia enim divina simplicitas excludit compositionem formae et materiae, sequitur quod in divinis idem est abstractum et concretum, ut deitas et deus. Quia vero divina simplicitas excludit compositionem subiecti et accidentis, sequitur quod quidquid attribuitur deo, est eius essentia, et propter hoc sapientia et virtus idem sunt in deo, quia ambo sunt in divina essentia" (ST1 q. 40, a. 1, ad 1).

47. We should also add, "relative to the time and modality of the copula." But we need not consider these complications here. Cf., however, the passage referred to in $\mathrm{n}$. 53 below and the related discussion in the text. In any case, using the notation introduced in $\mathrm{n}$. 40 , we could state this rule concerning assertoric (i.e., nonmodal, nonampliative) propositions in a formal system as follows: $\operatorname{SUP}(\mathrm{P})(\mathrm{t}) \in\{\mathrm{u}: \operatorname{SGT}(\mathrm{P})(\mathrm{u})(\mathrm{t}) \in \mathrm{A}(\mathrm{t})\}$, provided $\{\mathrm{u}: \operatorname{SGT}(\mathrm{P})(\mathrm{u})(\mathrm{t}) \in \mathrm{A}(\mathrm{t})\} \neq \varnothing$, otherwise $\operatorname{SUP}(\mathrm{P})(\mathrm{t})=0$, where $t$ is the time connoted by the copula of the proposition. From this and from the rules of $\mathrm{n}$. 40, it can be seen that an affirmative proposition whose subject supposits for nothing will have to be false. 
whereas God (the suppositum of the term 'God') is identical with deity, i.e., the significatum of the term 'God', and the suppositum (and significatum) of the term 'deity'. ${ }^{48}$

Note here that in the previous sentence the term 'humanity' is used to refer to what the term 'man' signifies. Indeed, in general, the function of abstract terms seems to be precisely this, namely, to afford us the linguistic means to refer in a proposition to the significata of their concrete counterparts, since the concrete terms do not refer to their significata but to the things actually having their significata. Thus, whenever we need to refer not to the supposita but to the significata of a concrete term, we need an abstract term, corresponding to the concrete term. We can therefore see how this semantic framework generated in scholastic philosophy and science the need for abstract terms even in cases in which ordinary usage did not supply any. It was this systematic need that yielded all the 'barbarisms' (such as lapideitas, asininitas, or even Sorteitas, and the Scotists' famous haecceitas and their like) that later on were to evoke the contempt of an emerging, new, nonscholastic intelligentsia, which originally refused and a couple of centuries later simply forgot to think in terms of the semantic principles governing scholastic discussions. But, of course, this is already a different and enormously complicated story, which we cannot go into here. Still, it is important to keep in mind that it is only as a result of this 'historical amnesia' that we are now in a situation in which it takes this meticulous gathering and arranging of bits and pieces of Aquinas's thought to piece together his semantic conception, consisting of principles that constitute a certain form of discourse, which was common in his time but for various reasons was gradually abandoned. In any cáse, we have now gathered enough of these bits and pieces to state at least some of the most general semantic principles that underly Aquinas's thought.

\section{AQUINAS'S SEMANTIC PRINCIPLES}

What follows will not be an exhaustive statement of what might be dubbed "Aquinas's semantics." Here I only summarize and briefly comment on some of the most general principles we could glean from the foregoing

48. Accordingly, if $[P]$ is the abstract counterpart of $P$, then we can say that $\operatorname{SGT}([\mathrm{P}])(\mathrm{u})(\mathrm{t})=\operatorname{SGT}(\mathrm{P})(\mathrm{u})(\mathrm{t})$, and $\operatorname{SUP}([\mathrm{P}])(\mathrm{t})=\operatorname{SGT}(\mathrm{P})(\operatorname{SUP}(\mathrm{P})(\mathrm{t}))(\mathrm{t})$, if $\operatorname{SGT}(\mathrm{P})(\operatorname{SUP}(\mathrm{P})(\mathrm{t}))(\mathrm{t}) \in \mathrm{A}(\mathrm{t})$, otherwise $\operatorname{SUP}([\mathrm{P}])(\mathrm{t})=0$. Thus, in a model representing Aquinas's metaphysics, the following will hold: SGT('God') $(\operatorname{SUP}($ 'God') $(\mathrm{t}))(\mathrm{t})=\operatorname{SUP}($ 'deity') $(\mathrm{t})=\operatorname{SUP}($ 'God') $(\mathrm{t})$; whereas SGT('man') $(\operatorname{SUP}($ 'man') $(\mathrm{t}))(\mathrm{t})=\mathrm{SUP}($ 'humanity') $(\mathrm{t}) \neq \mathrm{SUP}($ 'man') $(\mathrm{t})$. But of course other models may represent different metaphysics. In particular, the same semantic system permits even the case when SGT('man') $(\operatorname{SUP}($ 'man') $(\mathrm{t}))(\mathrm{t})=\mathrm{SUP}($ 'humanity') $(\mathrm{t})=\operatorname{SUP}\left({ }^{\prime} \operatorname{man}^{\prime}\right)(\mathrm{t})$. 
discussion. On this basis I will be able to answer all the questions and doubts that have emerged in the course of this discussion.

(1) Common terms signify human concepts immediately, and the forms of particulars represented by these concepts ultimately.

The point of this principle is that the signification of a common term is something it has because of being associated with some act of human understanding. An utterance or inscription becomes a term of a language precisely because of this association with, or subordination to, such a mental act. Once this conventional relation of subordination or immediate signification is established by an act of imposition or namegiving, the utterance or inscription becomes a term. Such a term, then, ultimately signifies the features, or forms, of the particular things represented by the concept to which it is subordinated. 49

Note that what I am here calling concepts are just certain acts of the human understanding on account of which a human being is able to use the terms of a language with understanding, whatever those acts are in themselves. Again, what I am here calling forms are just the features of the things represented by these acts of understanding, whatever those features are in themselves. Thus, concepts and forms, as just the immediate and ultimate significata (respectively) of our terms, are to be understood here in such a noncommittal way that any denial of their existence (in the intended sense) should be self-defeating. In this way, to claim, for example, that "I'm sure I have no such concepts in my head" in the intended sense of 'concept' would amount to the admission that "I can't use a single word with understanding, not even the words I'm now uttering." Again, if someone were to say, "Things just don't have such forms," then in the intended sense of 'form' this claim would imply the admission that "Nothing is characterized by anything, and so neither is the proposition I just uttered characterized by truth."

However, admitting such concepts and forms as (respectively) the immediate and ultimate significata of our terms need not involve any knowledge of what these significata are in themselves. In general, we can think of and hence signify and refer to things without knowing their nature. In fact, for most of the things we talk about we do not know what they are, whereas, of course, we know what we signify by their names. We are merely unable to give an essential definition of what is thus signified. For example,

49. Formally, if $\operatorname{CON}(\mathrm{m}, \mathrm{t})(\mathrm{P})$ is the concept to which $\mathrm{P}$ is subordinated in a mind $m$ at a certain time $t$-that is, the immediate significate of $P$ in $m$ at $t$-and $\mathrm{CON}(\mathrm{m}, \mathrm{t})(\mathrm{P})(\mathrm{u})(\mathrm{t})$ is what is represented by this concept in respect of the particular $u$ at time $t$, then the ultimate significate of $P$ in $u$ at $t$ can be defined as follows: $\operatorname{SGT}(\mathrm{P})(\mathrm{u})(\mathrm{t})=\operatorname{CON}(\mathrm{m}, \mathrm{t})(\mathrm{P})(\mathrm{u})(\mathrm{t})$. Notice how this formulation allows for conceptual change and hence for change of meaning of $P$. For details in this regard see Essay V of my Ars Artium. 
we can know what we signify by the term 'diamond' in English, without knowing that for something to be a diamond is for it to be a tetrahedrally crystalized allotrope of carbon. To know the latter is to know that the form signified by the term 'diamond' is the same as the form signified by the phrase 'tetrahedrally crystalized allotrope of carbon' (provided this is indeed what it is for something to be a diamond, but that is a question to be answered by natural scientists). But whether or not we are in possession of this piece of knowledge, by the term 'diamond' we signify this form, which we are certainly entitled to baptize by coining an abstract term, say, 'diamondhood', to be able to refer to it in further discussion. Of course, later on, it may turn out that what we referred to as 'diamondhood' is nothing but the tetrahedral arrangement of carbon atoms held together by covalent bonds, which we may further identify as the carbon atoms themselves thus and so arranged, and so on. But none of these later results should affect the validity of the original, semantic principle, which specifies how our terms are related to what they signify but says nothing about what these significata are in themselves. That is, it says nothing about what ontological category they belong to, or what combination of other terms would enable us to pick out precisely the same significata.

(2) A concrete common term $P$ is true of a particular thing $u$ iff the form (ultimately) signified by $P$ is actual in $u .50$

This principle is just a reformulation of the inherence theory: 'is actual' is meant to be taken in the same sense as 'is' or 'exists', the actual sense of which is determined by the signification of the actual substituents of P. For example, if $\mathrm{P}$ signifies a privation, then, of course, its significata can be actual only in the sense in which privations can be actual. ${ }^{51}$ They do not posit any entity in reality but rather indicate the lack of some real being in actual reality. Thus, for example, if 'bald' is construed as a privative term that signifies the lack of hair where there should be hair by nature, then the predication of 'bald' of a bald man is true because of the lack of hair on the bald man's head. It is the actuality of his baldness, the actual lack of hair on his head, that verifies the predicate 'bald'. But, of course, the actuality of this lack of hair does not make his baldness a real being superadded to the other, real entities of the world. Such a superadded real being would be the hair (or a wig, for that matter). But since it is precisely the actual lack of this superadded entity that is the actuality of baldness, the latter cannot be regarded as another such being, adding to the number of entities of the same kind. Hence, even if baldness is actual, it is in a sense different from the sense in which those real entities are. Indeed, even among real entities,

50. Cf. n. 40 above.

51. Cf. "et sicut in rebus, quae extra animam sunt, dicitur aliquid in actu et aliquid in potentia, ita in actibus animae et privationibus, quae sunt res rationis tantum" (In meta. 1b. 5, lc. 9, n. 13). 
which are not privations or just other beings of reason, there are further differences in their modes of being, reflected in the analogous senses of 'being' distinguished by Aristotle and Aquinas. I will have more to say about these in the next section.

(3) A concrete common term P supposits for (refers to) a particular thing $\mathrm{u}$ as the subject of a proposition iff the form signified by $\mathrm{P}$ in $\mathrm{u}$ is actual (relative to the time and modality of the copula of the proposition and to the ampliation of the predicate)..$^{52}$

The actuality of the significata of a common term is what makes it true of particular things, and so, if the term in question occurs as the predicate term of an affirmative categorical proposition, this will render the proposition true of the individuals referred to in it. But if the term in question is the subject term of a proposition, then its function is not to state something of the things referred to in the proposition but to refer, to supply the referents or supposita for the predicate term to be true of. However, even in this referring function, what determines whether a certain particular is actually supposited for by the common term as the subject term of a proposition is whether the form signified by the term in the particular is actual at the time consignified ${ }^{33}$ by the copula (or the verb implying the copula) of the proposition. For example, in the sentence 'A dinosaur is running', the subject term 'dinosaur' should supposit for actual dinosaurs - that is, things that actually have the nature of a dinosaur-for the sentence would be true only if the things actually having the significate of the subject would also actually have the significate of the predicate at the present time of the utterance of the proposition. But since by all probability there is no such thing in actuality (nothing has a dinosaur nature in actuality; i.e., nothing is a dinosaur), no such thing has the significate of the predicate in actuality, whence the sentence is actually false. However, in the proposition 'A dinosaur was running', the time consignified by the copula is some past time relative to the present time of the utterance of the proposition. So this proposition is true if the things which have or had the significate of the subject in actuality also had the significate of the predicate in actuality at some past time relative to the utterance of the proposition. But in that case, since some things did have dinosaur nature in the past (i.e., there were dinosaurs), and by all probability some of them were actually running at some past time (i.e., they had the significate of the predicate, the act of running, in actuality), this proposition is probably actually true.

Similar considerations would apply to other tenses, modalities, and special predicates habentes vim ampliandi, as medieval logicians would put

52. Cf. n. 47 above.

53. Cf., for example, In Peri lb. 1. lc. 5. 
it. These are predicates that have the force of extending the range of reference of their subject terms beyond the set of things that actually exist at the time of the utterance of the proposition, such as verbs and participles that signify mental acts (say, 'think', 'imagine', etc.). But we need not go into those details here. ${ }^{54}$ All we need to note here is that while reference depends on signification-for whether a particular thing has or does not have the significate of a common term ultimately determines whether or not it is supposited for in a proposition-nevertheless, this determination takes place in a propositional context, which further determines how these significata contribute to the determination of supposition. ${ }^{55}$

(4) The significata of the abstract counterpart [P] of a concrete common term $\mathrm{P}$ are the same as those of $\mathrm{P}$, but as the subject of a proposition $[\mathrm{P}]$ supposits for the ultimate significata of $\mathrm{P}$ (which are also the significata of [P], of course), provided they are actual relative to the time and modality of the copula of the proposition. ${ }^{56}$

The ultimate significata of abstract and concrete terms (and, hence, also their significations) are the same. Both 'white' and 'whiteness' signify the same forms, the individual whitenesses of particular things, whether they are actually or merely potentially white..$^{57}$ (There are, of course, things which cannot possibly be white, say, numbers, which are extra genus coloris,

54. Especially since St. Thomas never addressed ex professo the issue of suppositio, the medieval theory of reference. However, that he knew well and applied consciously the theoretical apparatus of the sophistae, the teachers of logic of the Faculty of Arts, is obvious from his references to their doctrine in the following places: $1 S N$ d. 21, q. 1, a. 1a, ad 2-um; ST1 q. 31, a. 3, ad 3-um; ST1 q. 39, a. 4, obj. 1; ST1 q. 39, a. 5, ad 5-um. For a discussion of Aquinas's doctrine in relation to the logical theory of his contemporaries, see Ashworth, "Signification," pp. 39-67. Also, for a discussion of ampliatio in particular, see G. Klima, "Old Directions in Free Logic: Existence and Reference in Medieval Logic," in New Directions in Free Logic, ed. K. Lambert (Sankt Augustin bei Bonn: Akademia Verlag, forthcoming).

55. Although Peter of Spain, for example, regards natural supposition as the kind of supposition a term has absolutely (per se), apparently even outside the context of a proposition. But even according to him, within a propositional context the actual (what he calls accidental) supposition of a term is determined by the context. See Peter of Spain, Tractatus, ed. L. M. de Rijk (Assen, Neth.: Van Gorcum, 1972), p. 81. For some discussion and further references see Klima, "Old Directions in Free Logic."

56. Cf. n. 48.

57. Cf., for example, the detailed discussion of denomination by Cajetan: "non debet denominativum differre a nomine formae denominantis in significatione. Hoc enim esset differre non solo casu sed significatione [interpunction mine]. Et consequenter diffinitione et essentia idem significat album et albedo, quum (ut infra docet Aristoteles) album puram qualitatem significat [cf. with this In meta. lb. 5 , lc. 9, n. 894]. Differentia autem in modo significandi inventa inter denominativum et denominans non excluditur per ly solo casu, quoniam talis differentia comes est differentiae secundum casum" (Scripta Philosophica, pp. 16-17). 
that is, are things for which color predicates are simply not interpreted. In such things color predicates signify nothing. ${ }^{58)}$ However, while concrete terms supposit for the things that have their significata in actuality, abstract terms supposit for their significata in actuality (relative to the conditions required by the propositional context). So whereas 'white' supposits for white things, 'whiteness' supposits for whitenesses, and so on. Of course, this does not tell us what kind of entity a whiteness is or, indeed, whether it is something distinct from a white thing. ${ }^{59}$

(5) An affirmative categorical proposition is true iff its predicate is true of (all or some, depending on the quantity of the proposition) of the supposita of its subject.

The truth of an affirmative categorical proposition-a proposition in which two common terms are joined by an affirmative copula-is ultimately determined by whether its predicate is true of the thing(s) supposited for by its subject term. Note that the terms here may be of any complexity, so the theory of categorical propositions need not be thought of as covering only simple cases like 'A man is an animal'. But here we need not deal with these complexities. ${ }^{60}$ Moreover, the truth of a categorical is determined by its quantity, that is, the determiner of its subject term, which determines how many of the supposita of the subject term should be considered in determining the truth of the proposition. In fact, this analysis of the categoricals allows for a uniform treatment of all sorts of determiners in the framework of a logical theory the expressive capacity of which matches that of generalized quantification theory. But again, such technicalities need not be considered here. ${ }^{61}$ The only really important point in the present discussion is that in accordance with this principle, the truth of a categorical proposition ultimately depends on whether its predicate is true of the supposita of its subject. But whether the predicate is true of these supposita depends on the actual inherence of its significata in these supposita. And so, since the actual inherence of these significata is nothing but their actuality, that is, their actual being, this point directly takes us back to the starting point of our discussion: the various analogical senses of 'being' distinguished by St. Thomas in accordance with the various modes of predication.

58. For this point, see again n. 40.

59. See again nn. 47 and 48.

60. For a detailed discussion of these complexities, see G. Klima, "Latin as a Formal Language: Outlines of a Buridanian Semantics," Cahiers de l'Institut du Moyen-Âge Grec et Latin, 61 (1991): 78-106.

61. Nevertheless, see Essay IV of my Ars Artium; or G. Klima and G. Sandu, "Numerical Quantifiers in Game-Theoretical Semantics," Theoria 56 (1990): 173-92. 


\section{BEING SIMPLICITER AND SECUNDUM QUID}

As we have seen, the theory of truth and predication outlined above in itself seems to require a systematic correspondence between the different kinds of significata of several sorts of predicates and the various analogical senses of 'being' distinguished by Aristotle and Saint Thomas. We have also seen, however, that according to St. Thomas's theory of the copula, the copula of an affirmative categorical proposition invariably signifies the truth of the proposition in which it occurs.

To see in more detail the relationships between the sense of the copula and the various senses in which the significata of several predicates can be said to be, let us take a more careful look at the various formulations of the inherence theory of predication provided above. All of these formulations are equivalences; the left-hand side states the truth of a predication, while the right-hand side states the actual existence of the significata of the predicate in the supposita of the subject of the predication. But a predication itself is performed by a categorical proposition, the formal element of which is the copula, which joins the terms to form a proposition. (Whether it is expressed in the surface structure of a language or not, the copula is necessary if a sequence of terms is to form a proposition. ${ }^{62}$ ) This is why we can say that what is invariably signified by the copula is the truth of the proposition in which it occurs. This is precisely the reason St. Thomas also often speaks about the mode of being that is signified by the copula as ens ut verum, "being as truth." 63 But stating the truth of the proposition is nothing but stating the obtainment of the state of affairs expressed by the proposition as a whole. In English the state of affairs expressed by a proposition can be referred to by a that clause, and in Latin it can be referred to

62. Of course verbs in this theory are to be analyzed into a copula and a participle. In fact, even in languages like Russian or Hungarian, in which no copula is needed for the formation of present-tense categoricals (although the two languages belong to different families of languages), the well-formedness of sentences in the past and future tenses requires the addition of the appropriate forms of the verb corresponding to the verb 'be'. This indicates that on the conceptual level a copula is present also in the present-tense sentences, even if it is unmarked in their surface syntax.

63. Cf. "Deinde cum dicit amplius autem ponit alium modum entis, secundum quod esse et est, significant compositionem propositionis, quam facit intellectus componens et dividens. Unde dicit, quod esse significat veritatem rei. Vel sicut alia translatio melius habet quod esse significat quia aliquod dictum est verum. Unde veritas propositionis potest dici veritas rei per causam. Nam ex eo quod res est vel non est, oratio vera vel falsa est. Cum enim dicimus aliquid esse, significamus propositionem esse veram. Et cum dicimus non esse, significamus non esse veram; et hoc sive in affirmando, sive in negando. In affirmando quidem, sicut dicimus quod Socrates est albus, quia hoc verum est. In negando vero, ut Socrates non est albus, quia hoc est verum, scilicet ipsum esse non album. Et similiter dicimus, quod non est diameter incommensurabilis lateri quadrati, quia hoc est falsum, scilicet non esse ipsum non commensurabilem" (In meta. lb. 5, lc. 9, n. 895). 
either by a clause beginning with a corresponding quod or quia or by an accusative with infinitive construction. ${ }^{64}$ Consider the following, equivalent sentences:
(1) $\mathrm{S}$ is $\mathrm{P}$
(2) ' $\mathrm{S}$ is $\mathrm{P}$ ' is true
(3) It is true that $\mathrm{S}$ is $\mathrm{P}$
(4) That $\mathrm{S}$ is $\mathrm{P}$ is true
(5) That $\mathrm{S}$ is $\mathrm{P}$ is
(6) That $\mathbf{S}$ is $\mathbf{P}$ is a being.

Aquinas's point seems to be precisely that all occurrences of 'is' (or rather the corresponding occurrences of 'est' in Latin), as well as the occurrence of 'being' in (6) above, express the same sense of 'being'. This sense, however, is not the primary sense but somehow analogically related to it. That is, all occurrences of ' $i s$ ' above, both as a copula and as an absolute predicate, express the same sense in which something can be said to be. Indeed, they express the same sense as that expressed by the predicate 'being' in (6), as well as in sentences such as 'A blindness is a being' ${ }^{65}$ In fact, any of the above formulations could stand on the left-hand side of an

64. For the early medieval theory of such sentential nominalizations, called appellatio dicti, see L. M. deRijk, ed., Logica Modernorum, II. 1. 2 (Assen, Neth.: Van Gorcum, 1967).

65. But how is it possible, one might ask, for both the copula and the predicate of 'A blindness is a being' to express the same sense? How could any absolute predicate have the same sense as the copula? Well, using ' is $_{2}$ ' to distinguish the usage of 'is' when it is used in the ens rationis sense, and using 'being, to distinguish the usage of 'being' when it is used in the ens rationis sense, we can say first, in general, that 'is ${ }_{2}$ ' signifies the same whether it is used as a copula of a proposition or as the absolute predicate of a significate of the predicate of the same proposition: $\mathrm{SGT}\left({ }^{\mathrm{is}}{ }_{2}\right.$ ') $(\mathrm{SGT}(\mathrm{P}))(\mathrm{SUP}(\mathrm{S})(\mathrm{t}))(\mathrm{t})=\mathrm{SGT}\left({ }^{\mathrm{i} \mathrm{is}_{2}}{ }^{\prime}\right)(\mathrm{SGT}(\mathrm{P})(\mathrm{SUP}(\mathrm{S})(\mathrm{t}))(\mathrm{t}))(\mathrm{t})$; that is, given that, in accordance with rule $(4), \operatorname{SGT}(\mathrm{P})(\mathrm{SUP}(\mathrm{S})(\mathrm{t}))(\mathrm{t})=\mathrm{SUP}([\mathrm{P}])(\mathrm{t})$, $\operatorname{SGT}\left({ }^{\prime i s_{2}}{ }^{\prime}\right)(\operatorname{SGT}(\mathrm{P}))(\operatorname{SUP}(\mathrm{S})(\mathrm{t}))(\mathrm{t})=\mathrm{SGT}\left({ }^{\prime} \mathrm{is}_{2}{ }^{\prime}\right)(\operatorname{SUP}([\mathrm{P}])(\mathrm{t}))(\mathrm{t})$, which is precisely to say that ' $\mathrm{is}_{2}$ ' both in 'An $\mathrm{S}$ is ${ }_{2} \mathrm{P}$ ' and in 'A $[\mathrm{P}]$ is $_{2}$ ' signifies the same, or has the same sense. But then, further, we can say that SGT ('is ${ }_{2}$ ') $(\operatorname{SUP}([\mathrm{P}])(\mathrm{t}))(\mathrm{t})=$ SGT ('being ${ }_{2}$ ') (SUP ([P]) (t)) (t), which is nothing but to claim that ' $\mathrm{is}_{2}$ ' and 'being ${ }_{2}$ ' as absolute predicates of the supposita of $[\mathrm{P}]$ signify the same. In general, $\operatorname{SGT}\left({ }^{\prime i s_{2}}{ }^{\prime}\right)(\operatorname{SGT}(\mathrm{P}))(\operatorname{SUP}(\mathrm{S})(\mathrm{t}))(\mathrm{t})=\operatorname{SGT}\left({ }^{\prime} \mathrm{being}_{2}{ }^{\prime}\right)(\operatorname{SUP}(\mathrm{S})(\mathrm{t}))(\mathrm{t})$. Whence, in particular, SGT ('is ') (SUP('blindness') (t)) (t) = SGT ('is ') (SGT ('being ') )

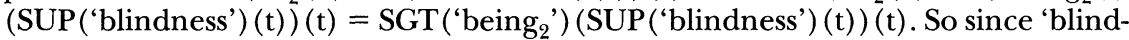
ness' supposits for a privation, we say that blindness is and it is a being, but it is and it is a being precisely and only in this sense, namely, in the sense that is also expressed by the copula of an affirmative proposition. For the different case of 'sight' see n. 69. Indeed, even further, SGT ('is ${ }_{2}$ ') $(\operatorname{SUP}($ 'blindness') $(\mathrm{t}))(\mathrm{t})=$ SGT ('is 2 ') (SGT ('blind')) (SUP(S) (t)) (t); that is, when we say that a blindness is, the predicate of this sentence signifies the same as what is signified by the copula of the sentence by which we assert that an $\mathrm{S}$ is blind, precisely as Aquinas says (see In meta. lb. 5 , lc. 9 , n. 896, quoted just below). 
equivalence, stating the inherence theory of predication. However, on the right-hand side we would have to have formulations of the following sort (where $[\mathrm{P}]$ is the abstract form of $\mathrm{P}$ ):

(7) A significate of $\mathrm{P}$ in a suppositum of $\mathrm{S}$ is (is actual/exists)

(8) A [P] of an $\mathrm{S}$ is (is actual/exists)

(9) A [P] of an $\mathrm{S}$ is a being.

Note that here it is only the italicized copulae of these schemata that express the same sense as the occurrences of 'is' in (1)-(6). The other occurrences of 'is', as well as occurrences of 'actual', 'exists', and 'being', express different senses of 'being', depending on what sort of entity is signified by $\mathrm{P}$ in a suppositum of S. For example, with 'blind' as the privative opposite of 'sighted', and 'blindness' and 'sight' as their respective abstract forms, consider the following instances of a scheme that expresses the inherence theory of predication:

(10) A man is sighted if and only if the sight of a man is (is a being)

(11) A man is blind if and only if the blindness of a man is (is a being).

St. Thomas's point seems to be that here the italicized occurrences of 'is' (and 'being') signify being in the same sense:

We should know that this second mode is compared to the first as effect to cause. For it is from there being something in the nature of things that the truth or falsity of a proposition follows, which the intellect signifies by the verb 'is' as it is a verbal copula. But, since something which in itself is not a being, as a negation and the like, is considered by the intellect as some being, sometimes that it is is said of something in this second way, but not in the first. For it is said that blindness $i s$, in the second way, because the proposition by which something is said to $b e$ blind is true; but it is not said that this is true in the first way. For blindness does not have some being in the things, but it is rather a privation of being. ${ }^{66}$

However, the nonitalicized occurrence of 'is' (as well as that of 'being') in (10) signifies being in the sense contrasted with the ens-rationis sense, as expressing real being, ens reale, which itself comprises both the primary sense and several other secondary senses:

We have to say that 'being' is predicated in two ways.... In one way as it is a verbal copula signifying the composition of any proposition that the soul forms: whence this being is not something in the nature of things,

66. In meta. lb. 5 , lc. 9 , n. 896 . 
but only in the act of the judgment-forming intellect. And in this way being is attributed to everything of which a proposition can be formed, whether it is a being or a privation of being: for we say that blindness $i$. In the other way being [esse] is said to be the act of being [ens] insofar as it is a being, that is, that by which something is denominated as a being in the nature of things. And being in this way is attributed only to the things themselves which are contained in the ten categories, whence 'being' [ens] predicated on account of such [an act of] being [esse] is divided by the ten categories. But this [act of] being [esse] is attributed to something in two ways. In one way as to that which [quod] properly and truly has being, or is. And thus it is attributed only to a per se subsisting substance; whence, in bk. 1. of the Physics, that which truly is is said to be a substance. All those [things], however, which do not subsist per se, but in others and with others, whether they are accidents or substantial forms or any sorts of parts, do not have being [esse] so that they themselves would truly be, but being [esse] is attributed to them in another way, namely, as to something by which [quo] something is; as whiteness is said to be, not that it itself would subsist in itself, but because it is by it that something has it that it is white. Being, therefore, is properly and truly attributed only to a per se subsisting thing. To this, however, two kinds of being are attributed. The one is what results from those from which its unity is integrated, which is the proper substantial being of a suppositum. Another being is attributed to a suppositum besides those that integrate it, which is an additional being, namely, accidental being; as being white is attributed to Socrates when it is said: Socrates is white. ${ }^{67}$

So, if in

(i) An $\mathrm{S}$ is $\mathrm{P}$

$\mathrm{P}$ signifies a privation (or negation or relation of reason ${ }^{68}$ ), then in the corresponding

(ii) $\mathrm{A}[\mathrm{P}]$ of an $\mathrm{S}$ is

'is' signifies being in the secondary, ens-rationis sense, inasmuch as the two propositions are equivalent. Of course, nothing prevents anyone from asserting, say, that [a] blindness is, or [an] evil exists, intending to signify that blindness and evil are real beings, that is, taking 'is' or 'exists' in the sense in

67. $Q D L 9$, q. 2, a. 2, in corp.

68. Although here I take only privations as my examples of beings of reason, it is not only privations that were regarded as such by St. Thomas. Indeed, according to him, the proper subject matter of logic consists of beings of reason of a different sort: relations of reason. For a thoroughgoing discussion of St. Thomas's conceptions of the subject of logic, see R. W. Schmidt, The Domain of Logic according to Saint Thomas Aquinas (The Hague: Martinus Nijhoff, 1966). For a discussion of various sorts of entia rationis and their systematic role in medieval semantics, see G. Klima, "The Changing Role of Entia Rationis in Medieval Philosophy: A Comparative Study with a Reconstruction," Synthese 96:1 (1993): 25-59. 
which they signify the actuality of real being. But if the terms 'blindness' and 'evil' are genuinely privative, in the way they were interpreted by St. Thomas, these assertions simply will not be true. However, if $\mathbf{P}$ signifies a real being, then, while the copula of (i) will still express being in the ens-rationis sense, 'is' in (ii) will signify some real being. For example, if the proposition 'A man is sighted' is true, then 'A man's sight is' will also be true, so that while the occurrence of 'is' as the copula of the first proposition signifies being in the ens rationis sense, the occurrence of 'is' as the predicate of the second proposition signifies being in an ens reale sense. ${ }^{69}$ Again, of course, one may wish to claim that a man's sight is, or exists, or that there is such a thing as a man's sight, in the ens rationis sense, in which sense the claim thus made will also be true since whatever is a real being also exists in this weaker, ens rationis sense according to St. Thomas. But the point is that, unlike the case of 'A man is blind' and 'A man's blindness is', if 'A man is sighted' is true, then 'A man's sight is' will also be true even when 'is' is taken in the latter case in an ens reale sense. However, as we have seen, given that a man's sight is not a substance, even this is not the primary sense of 'is' but only one of the several senses analogically related to its primary sense, namely, the sense in which we can say of a substance that it is.

Perhaps, in view of what has been said so far, we can now see how Aquinas is able to base this distinction between the primary and the secondary senses in which a real being can be said to be on the distinction between that which is, quod est, and that by which something is, quo aliquid est, which is based in turn on a distinction between what he regards as the predication of 'being' or 'is' simpliciter and secundum quid. The clue, of course, lies in the inherence theory of predication and in the related theories of signification and supposition. In accordance with these, when a substance $u$ is said to be, say, white, this is equivalent to saying that the whiteness of $u$ exists. We can say, then, that for $\mathrm{u}$ 's whiteness to be is nothing other than for $\mathrm{u}$ to be white, which is further for $\mathrm{u}$

69. Of course, the absolute predicate 'is', expressing an ens-reale sense, could be analyzed further into 'is a being'. In this case ' $i s$ ' would express the ens-rationis sense and 'being' an ens-reale sense. Using ' $\mathrm{is}_{1 / 2}$ ' and 'being ${ }_{1 / 2}$ ' to distinguish the usage of 'is' and 'being', respectively, in which they express the sense in which they are truly predicated of really inherent accidental forms but not of mere beings of reason, we can say that $\operatorname{SGT}$ ('is ${ }_{1 / 2}$ ') $(\operatorname{SUP}$ ('sight') $(\mathrm{t}))(\mathrm{t})=\mathrm{SGT}$ ('being ${ }_{1 / 2}$ ')

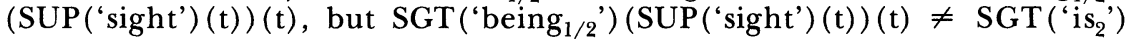
$\left(\mathrm{SGT}\right.$ ('being $1 / 2$ ')) (SUP('sight') (t)) (t), whereas, of course, SGT('is ' $^{\prime}$ ) (SGT('be$\operatorname{ing}_{1 / 2}$ ')) (SUP('sight') (t)) (t) = SGT('is ') $(\operatorname{SUP}$ ('sight') (t)) (t). So, what 'is' signifies in a secondary ens reale sense in a suppositum of 'sight' at the time of uttering 'A sight is' is the same as what 'being' signifies in the same sense in respect of the same at the same time in the utterance 'A sight is a being', but this is not identical with what the copula of this latter utterance signifies at the same time in respect of the signification of the predicate ('being') and the suppositum of 'sight' at the same time, which is nevertheless nothing, but what would be signified by 'is ${ }_{2}$ ' in the sentence 'A sight is ${ }_{2}$ ', claiming the existence of sight in the ens rationis sense. Cf. with this the analysis of 'A blindness is a being' in $\mathrm{n} .65$ above. 
to be not absolutely (simpliciter) but with respect to something (secundum quid), namely, with respect to its whiteness. As St. Thomas says,

\begin{abstract}
Substance is the first being, and is being absolutely [simpliciter], and not being with respect to something, i.e., with qualification [secundum quid], as is the case with accidents. For to be white is not to be absolutely [simpliciter esse], but with qualification [secundum quid]. And this is clear from the fact that when something begins to be white, we don't say that it begins to be, absolutely, but that it begins to be white. For when Socrates begins to be a man, we say absolutely that he begins to be. Whence it is clear that to be a man signifies to be, absolutely. But to be white signifies to be with qualification. ${ }^{70}$
\end{abstract}

Thus we can see exactly how Aquinas can interpret all predications as predications of being, either with or without qualification. Just as in "ordinary predications" we can attach various qualifications to the predicate, so these "ordinary predications" themselves may be regarded as various qualifications of the predication of being. According to this analysis, therefore, when we say, 'A man is blind', this is equivalent to saying, 'A man's blindness is' which in turn, is equivalent to saying, 'A man is with respect to his blindness'.

It is this last formulation which shows explicitly why we can say that the attribution of blindness to a man is an attribution of being to him (insofar as we say that he is with respect to something), although not simpliciter but secundum quid (insofar as we say that he is with respect to something). Moreover, it shows that this attribution is at the same time an attribution of being to his blindness (insofar as what is signified by the complex predicate 'is with respect to blindness' in him is identical with what is signified by 'is' in his blindness, and which in turn is identical with what is signified in him by 'is blind'). ${ }^{71}$ However, given the privative character of the predicate 'blind', the being thus attributed is, and can only be, being in the ens rationis sense, which is nothing but the lack of real being being conceived by the intellect as a form signified by the predicate 'blind'. So we can see how we should understand that the being of a privation (or of any other ens rationis, for that matter) is being in the intellect, having some foundation in reality. Being in the intel-

70. In meta. lb. 7, lc. 1, n. 1256. Cf. De Principiis Naturae c. 1.

71. Using 'is ${ }_{2}$ ' again in the same way as above, and using 'is ${ }_{1}$ ' to distinguish the usage of 'is' in which it is truly predicable in its primary sense of substances, we can

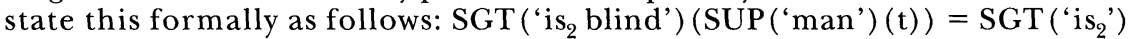

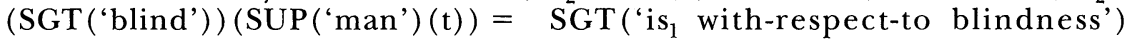

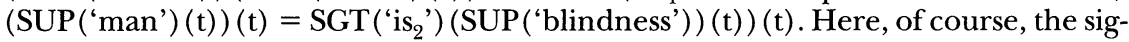
nification of the complex, qualified predicate can (and, to comply with the requirement of compositionality, should) be analyzed further as follows: SGT ("is with-respect-to blindness') = SGT ('with-respect-to') (SGT('is, ')) (SUP('blindness') $(\mathrm{t}))$. (The phrase 'with-respect-to' need not be analyzed because it functions as a single modifier. Indeed, in Latin the one-word phrase respectu, as in homo est respectu caecitatis, or secundum, as in homo est secundum caecitatem, would do the same job.) 
lect is nothing other than being conceived by the human intellect, which we can express by predicates that signify acts of human awareness, as when we say that a chimera is thought of. In fact, even this predication can be construed as a predication of being secundum quid (which may be expressed by saying that a chimera is with respect to its being thought of), but the sense of being that is predicated in this case is not even the ens rationis sense, which Aquinas says is the sense in which we can answer a question that asks whether there is such and such a thing. For, of course, to the question of whether there are chimeras, it would not be an appropriate answer to say that yes, there are, insofar as they are thought of. However, to the question of whether there is blindness, it is an appropriate answer to say that yes, there $i s$, insofar as some animals that should have sight by nature actually lack sight, which is precisely what is conceived of in the concept of blindness.

Note here that for the being of blindness, both conditions are required: both the lack of some sight and the activity of the human intellect to conceive of this lack of sight by forming the concept of blindness. Were there no humans to form the concept of blindness, there would be no blindness, even if there were animals that lacked sight, for the actuality of blindness consists in the actual lack of sight conceived by humans by applying the concept of negation to the concept of sight (in forming the concept of blindness as an animal's lacking, i.e., not having sight). ${ }^{72}$ In contrast, the actuality of sight does not involve any such activity of the human mind, for if there were sighted animals, there would be sights in actual reality, even if there were no

72. At this point one might object that if there are animals that lack sight, then there must be blindnesses also, even if there are no minds to conceive of them, given that for a blindness to be is nothing but for a sight not to be. (In fact, I received this objection from Scott MacDonald.) Well, it is true that for a blindness to be is for a sight not to be, in the sense privations and negations can be; that is, SGT ( ${ }^{2} s_{2}$ ') $($ SUP ('blindness') $(\mathrm{t}))(\mathrm{t})=\mathrm{SGT}$ ('not') $\left(\mathrm{SGT}\right.$ ('is ${ }_{2}$ ') ) (SUP('sight') (t)) (t). Here, of course, SGT ('not') $(\operatorname{SGT}(\mathrm{P}))(\operatorname{SUP}(\mathrm{S})(\mathrm{t}))(\mathrm{t}) \in \mathrm{A}(\mathrm{t})$, if $\operatorname{SGT}(\mathrm{P})(\operatorname{SUP}(\mathrm{S})(\mathrm{t}))(\mathrm{t}) \in \mathrm{W}$ $\mathrm{A}(\mathrm{t}), \operatorname{SGT}$ ('not') (SGT $(\mathrm{P}))(\mathrm{SUP}(\mathrm{S})(\mathrm{t}))(\mathrm{t}) \in \mathrm{W}-\mathrm{A}(\mathrm{t})$, if SGT $(\mathrm{P})(\mathrm{SUP}(\mathrm{S})(\mathrm{t}))(\mathrm{t})$ $\in A(t)$, and SGT ('not') $(\operatorname{SGT}(\mathrm{P}))(\operatorname{SUP}(\mathrm{S})(\mathrm{t}))(\mathrm{t})=0$ if SGT $(\mathrm{P})(\operatorname{SUP}(\mathrm{S})(\mathrm{t}))(\mathrm{t})=0$

(Note how these rules provide the conditions for an internal negation, the truth of which presupposes that the negated predicate is interpreted for the subject of which it is denied. This is how we can do justice to the intuition that, say, the number 2 is neither sighted nor blind.) Still, even if there are no blindnesses, that is, SGT('is ${ }_{2}$ ') (SUP('blindness') ( $\left.\left.\mathrm{t}\right)\right)(\mathrm{t}) \notin \mathrm{A}(\mathrm{t})$, it is quite possible that there are no sights either: SGT ('is ${ }_{1 / 2}$ ') (SUP('sight') $\left.(\mathrm{t})\right)(\mathrm{t}) \notin \mathrm{A}(\mathrm{t})$. So even if there are no sights in the sense sights could be because, say, all animals lack sight, still it is quite possible that there are no blindnesses either in the sense blindnesses could be (that is, in the sense that they are conceived and have the foundation in reality required by their concept) because there are no minds to form the concept of negation and hence to be able to conceive of them. In fact, we can say that in the case when there are no minds to form the concept of negation SGT ('is, ') (SUP('blindness') (t)) ( $t)=$ SGT ('not') (SGT ('is $\left.{ }_{2}^{\prime}\right)$ ) (SUP('sight') $\left.(\mathrm{t})\right)(\mathrm{t})=0$. But of course with this it is compatible that SGT( 'is ${ }_{1 / 2}$ ') (SUP('sight')(t)) (t) $\notin \mathrm{A}(\mathrm{t})$, and even that SGT ('is ${ }_{2}$ ') (SUP('sight') (t)) (t) $\notin \mathrm{A}(\mathrm{t})$. In brief, whenever there is no sight, there is no being of a sight either, but this does not mean that then there also has to be the being of the nonbeing of sight conceived by an intellect. 
humans to conceive of them. The difference is that what we conceive of by the concept of blindness involves, in its very concept, some mental act (in this case negation), whereby it can be said to be only if the relevant mental act exists. However, even if the concept of sight is a mental act in itself, it does not involve any mental act in what is conceived of by it, whence what is conceived of by it can exist whether there are any mental acts in reality or not. Thus, the difference between a real being and a (mere) being of reason is the mind-dependence of the latter. However, the difference between a being of reason and a mere object of thought (and hence an object of signification and reference) is precisely that the former has some foundation in reality, namely, the way real beings are, as conceived of in the concept of the being of reason in question. So we can say that for a mere object of thought to be is nothing but for it to be thought of. But for a being of reason to be, in the sense in which, say, a privation is, is for it to be thought of and for something that is conceived of in its concept also to obtain in the realm of real beings. In the case of a privation, for it to be is for it to be thought of and for its real opposite not to be. ${ }^{73}$

Thus, Aquinas's "universe of discourse" consists primarily of objects of thought, that is, whatever human beings can think of and hence signify (by external, spoken or written words) or refer to in the context of a proposition. Therefore, since a chimera can be thought of, 74 and hence since the proposition 'A chimera is thought of', in which reference is made to a chimera, can be true, a chimera can be said to be one of the things that can be thought of, signified, or referred to. Still, of course, it is not true to say that what is thought of when a chimera is thought of, or what is referred to in the proposition 'A chimera is thought of', is a chimera. For nothing is a chimera. Thus a chimera cannot be said to be at all, except perhaps in the very thin sense of possibly being thought of, in the sense of 'being' Walter Burleigh called 'ens maxime transcendens'.75

73. Thus, the actuality of a being of reason is conditioned both on the side of reality and on the side of the activity of the intellect. So if either of these two fails to obtain, a being of reason will not be in actuality, just as it was technically detailed in n. 72 .

74. Of course, insofar as we construe 'chimera' as referring to a possible imaginary animal, and not an implicitly contradictory term, in the way fourteenthcentury logicians used this term. For more on this issue see E. J. Ashworth, "Existential Assumptions in Late Medieval Logic," American Philosophical Quarterly 10 (1973): 141-47. Cf. Klima, "Old Directions in Free Logic."

75. “. . . ens potest accipi tripliciter. Uno modo ut est maxime transcendens et commune omni intelligibili. Et sic est adaequatum obiectum intellectus. Et sic non sequitur: Hoc est ens, ergo hoc est. Secundo modo accipitur pro ente, cui non est esse prohibitum, et sic omne possibile est ens. Et sic etiam non sequitur: Hoc est ens, ergo hoc est. Tertio modo accipitur pro ente actualiter existente, et sic est participium descendens ab hoc verbo 'est'. Ens primo modo dictum dicitur ens in intellectu, quia est obiectum intellectus; et ita est in intellectu obiective. Ens secundo modo dictum dicitur ens in suis causis vel ens quod est in sua causa. Sed ens tertio modo dictum dicitur esse ens in se." W. Burleigh, De Puritate Artis Logicae Tractatus Longior, ed. P. Boehner (St. Bonaventure, N.Y.: Franciscan Institute, 1955), pp. 58-59. 
But this is not the sense of 'being' in which St. Thomas calls something a being of reason, the sense in which to say of something that it is answers the question of whether there is such a thing. Thus the domain of beings of reason forms a subdomain of Aquinas's universe of discourse, comprising both real beings and mere beings of reason but excluding mere objects of thought. A being of reason can properly be said to be in the sense in which a being of reason can be at all, that is, in the sense that is signified by the copula of an affirmative proposition. But we have seen that the being that is signified by a copula is not signified only by a copula, for being is signified in the same sense by 'is' as the predicate, say, in the sentence 'A blindness is' (or by 'being' in 'A blindness is a being'), as this sentence is true. ${ }^{76}$ This sense of 'is' or 'being' is analogically related to the sense in which really existing substances are said to be. But then, just as any analogical sense of a common term is derived from its primary sense by some determination or qualification of its primary sense, so this (as well as any other, analogical sense of 'being') is derived from its primary sense by some qualification of it. In general, the predication of being (by means of predicating 'is' or 'being' or 'is P') in any of its analogical, secondary senses is the predication of being in its primary sense with some determination or qualification. And since in view of the inherence theory of predication every predication is a predication of being, either in its primary or in one of its analogical senses, every predication is a predication of being either without or with some qualification, either simpliciter or secundum quid. ${ }^{77}$

To see this relationship between predication and the predication of the several analogous senses of being in general, consider the following scheme:

(EP) (i) An S is $s_{2} P$ iff (ii) An S's [P] is iff $_{x}$ (iii) An S is $s_{1}$ with respect to $[\mathrm{P}]^{78}$

In this scheme the subscripts to 'is' are designed to distinguish the various senses in which being is signified in the given propositional context, insofar as the proposition is or can be true (for, of course, anyone may intend to use 'is' in a different sense in a given context, but then, in that use, his or her

76. See nn. 65 and 69 above.

77. Cf. n. 71. Note that when I am talking about 'the predication of being' in a certain 'sense of being', I mean the act of predicating either the absolute predicate 'is' or the predicate 'being' or 'is a being' or the complex 'is P' or 'is with respect to $\mathrm{P}$ ' in the sense of 'is' or 'being' required by the context for the truth of the predication.

78. In such a "chain" of equivalences, the logically squeamish would certainly look for parentheses (as in ' $p$ iff ( $q$ iff $p)$ '), but in vain. Such "chains" of equivalences are intended only to abbreviate a series of proper equivalences. Thus, '(i) iff (ii) iff (iii)' abbreviates '(i) iff (ii) and (ii) iff (iii)'; that is, this is just a brief expression of the idea that each member of the chain is equivalent to any other member. Of course the same applies to such "chains" of any number of members. 
proposition may be necessarily false or even ill formed). Accordingly, in (i) 'is,' signifies being in the ens rationis sense, the sense uniformly expressed by the copula, as well as by 'is' or 'exists' as absolute predicates, insofar as they are true of beings of reason; in (ii) 'is s' signifies being in any of the analogical senses of being (including the ens rationis sense); and, finally, in (iii) 'is,' signifies being in the primary sense, the sense in which it can truly be stated of substances as an absolute predicate, to signify their actuality absolutely speaking, as well as a predicate with some qualification, to signify their actuality in some determinate respect.

Let us see, then, exactly how the various kinds of substitutions of $\mathrm{P}$ affect what sense of being is expressed by ' ${ }^{\prime}{ }_{x}$ ' in (ii) insofar as it is true. If we substitute for $\mathrm{P}$ a term that signifies an ens rationis (which is not a real being), such as the term 'blind', then the equivalences of (EP) will hold if we take ' $\mathrm{is}_{\mathrm{x}}$ ' to be ' $\mathrm{is}_{2}$ ', that is, if we take ' $\mathrm{is}_{\mathrm{x}}$ ' in (ii) to express the ens rationis sense of being as it was contradistinguished by St. Thomas from the ens reale sense. Thus, substituting 'blind' for $\mathrm{P}$ and 'animal' for $\mathrm{S}$, we get the following valid instance of $(\mathrm{EP})$ :

$\left(\mathrm{E}_{2} \mathrm{P}\right)(\mathrm{i})$ An animal is $\mathrm{s}_{2}$ blind iff (ii) The blindness of an animal is $\mathrm{s}_{2}$ iff (iii) An animal is ${ }_{1}$ with respect to blindness

Note that in (ii) 'is ${ }_{2}$ ' could be analyzed further as ' $\mathrm{is}_{2}$ a being,', which in turn is equivalent to ' ${ }^{2}{ }_{2}$ a being ${ }_{1}$ of reason'. ${ }^{79}$ This is how the secondary, ens rationis sense of being can be shown to be derivable from the primary sense by the addition of the appropriate (in this case, diminishing) qualification. Of course, this is why the inference from 'A blindness of an animal is' is, 'A blindness of an animal is ${ }_{2}$ a being ${ }_{1}$ of reason', to 'A blindness of an animal is ${ }_{1}$ ', that is, 'A blindness of an animal is ${ }_{2}$ a being ${ }_{1}$ ', would be invalid. Thus, Aquinas can justifiably claim that a (mere) being of reason is not a being, except secundum quid.

But then one might ask why the inference secundum quid ad simpliciter in the case of (iii) would be valid. For we can certainly infer from (iii) that an animal is, indeed, absolutely and in the primary sense of being. According to the equivalences given above, (iii) is equivalent to (i), and (i) certainly implies that an animal is, for no animal can be blind unless it exists. But if the above equivalences also show how this secondary sense of being is derivable from the primary sense by adding the appropriate, diminishing qualification, then the act of being signified by the predicate of (ii) is the same as the act of being signified by the qualified predicate of (iii). Indeed, it is precisely this qualification that modifies the sense of the predicate in such a way that it signifies an act of being in this secondary sense (in this case, the actuality of the blindness of an animal) instead of

79. In fact, SGT ('being ${ }_{1}$ of reason') = SGT('is $\left.{ }_{2}^{\prime}\right)=$ SGT ('being ${ }_{2}$ '). Cf. nn. 65 and 69 . 
what it would signify without this qualification (an act of being in the primary sense). However, in the case of (ii) we could not conclude from the actuality of the act of being signified by the predicate of (ii) to the actuality of the act of being signified by 'is ' absolutely. So why can we do so in (iii)?

The answer is straightforward if we consider these inferences themselves. ${ }^{80}$ In the case of (ii) the conclusion stated in itself would state the existence of a blindness of an animal in the primary sense of being, in which sense this claim could not be true. However, in the case of (iii) the conclusion in itself states the actual being of an animal in the primary sense, which of course is implied by the existence (in the secondary sense) of its blindness. So although it is indeed the same act of being that is signified both by the predicate of (ii) and by the qualified predicate of (iii) (a very important point to which I shall return), the subjects of the conclusions of these inferences secundum quid ad simpliciter are not the same. Therefore, the two inferences have nothing to do with each other.

Still, one might insist that the validity of the inference secundum quid ad simpliciter in the case of (iii) seems to invalidate the general rule concerning such inferences, namely, that if the qualification added to the predicate is diminishing, then the inference is invalid, whereas the equivalences above show precisely that the qualification in (iii) is diminishing.

This objection rests on a misunderstanding of what a formal rule of inference is. Even if an inference is not valid in its form, nothing prevents it from being valid on the basis of the actual meaning of its terms. For example, even if an inference of the form 'an $S$ is $M$, and an $M$ is $P$; therefore an $\mathrm{S}$ is $\mathrm{P}$ ' is formally invalid (as can be shown by substituting 'man', 'animal,' and 'donkey' for S, M, and P, respectively), an inference of that form can be valid because of the meaning of the particular terms (for example, if we substitute 'man', 'animal,' and 'living being' for S, M, and P, respectively). But then, in the same way, although an inference of the form 'An $\mathrm{S}$ is 2 P with respect to [Q]; therefore an $\mathrm{S}$ is ${ }_{2} \mathrm{P}$ ' is formally invalid if 'with respect to [Q]' is a diminishing qualification of $\mathrm{P}$-but formally valid if 'with respect to $[\mathrm{Q}]$ ' is a nondiminishing qualification of $\mathrm{P}$-nothing prevents an inference of this form from being valid because of the meaning of its terms even if it is formally invalid, that is, even if the qualification of the predicate is diminishing. Indeed, the particular reason why in the case of (iii) such an inference (that is, the one resulting from substituting 'is, or 'is a being $_{1}$ ' for 'is 2 P', as well as, 'blindness' for [Q], namely, 'An animal is $_{1}$ with respect to blindness; therefore an animal is ${ }_{1}^{\prime}$ ) would be valid,

80. Namely, 'The blindness of an animal is s $_{2}$, therefore, a blindness is ${ }_{1}$ ', and 'An animal is ${ }_{1}$ with respect to blindness; therefore an animal is ${ }_{1}$. The question is why the first inference is invalid while the second is valid, given that SGT( ' $\mathrm{is}_{2}$ ') (SGT ('blind') (SUP('animal') (t)) (t)) (t) = SGT ('is $1_{1}$ with-respect-to blindness') $\left(\operatorname{SUP}(\right.$ 'animal') $(\mathrm{t}))(\mathrm{t})$, where, of course, SGT('is ${ }_{1}$ with-respect-to blindness') = SGT ('with-respect-to') (SGT ('is ${ }_{1}^{\prime}$ )) (SGT ('blind')) = SGT('is,') (SGT('blind')). Cf. n. 71 . 
despite the fact that the qualification is diminishing, is that a privation is a lack of a property in a determinate subject, so if the privation is actual, then the subject has to be actual too. ${ }^{81}$ That the inference is still formally invalid if the qualification is diminishing is shown by the fact that by substituting 'is ${ }_{1}$ ' or ' $i s_{2}$ a being' ' for ' $i s_{2} P$ ' and, say, 'being thought of' for [Q] in this rule of inference, the resulting inference, 'An animal is ${ }_{1}$ with respect to

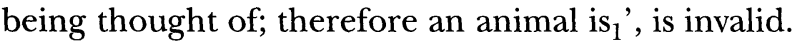

Thus, if in (EP) we substitute for $\mathrm{P}$ a predicate that signifies a being of reason, the qualification added to 'is, ' in (iii) modifies its sense in such a way that the resulting complex, qualified predicate will signify the same act of being as that signified by 'is ${ }_{2}$ ' as an absolute predicate in (ii) or by the equivalent phrases 'is a being in the secondary, ens rationis sense', 'is a being of reason', 'is a being in thought having some foundation in reality', and so on, all signifying being in the same, diminished, qualified sense. So the qualification in this case yields a sense of being in which it is predicable even of objects of thought that exist neither in the primary sense of subsisting, nor in the secondary sense of being some really inherent property of a subsistent being, but only in the sense of being conceived by the human mind and having for their actuality some foundation in reality, some particular way real beings actually are, as was explained above.

On this basis we can perhaps better understand what it is for a qualification to be diminishing and how the addition of diminishing qualifications is related to analogical predication in general. The first interesting thing to note about a diminishing qualification is that, to put it in contemporary terms, while it is intensionally diminishing, it is extensionally "enlarging." The point is that a diminishing qualification is one that takes away some of the conditions of the strict applicability of the term to which the qualification is added. Hence the term with the qualification added becomes applicable even to things to which in its strict usage, without the diminishing qualification, it could not apply. For example, if to the predicate 'white' we add the qualification 'with respect to its one-half', then the qualified predicate will apply even to things which strictly speaking and without this qualification could not be called white, since properly and strictly speaking only things that are white with respect to their whole surface can be said to be white without qualification. Indeed, this also shows immediately that the qualification 'with respect to its whole surface' is a nondiminishing qualification of 'white', ${ }^{82}$ whence in a predication it

\section{Cf. n. 72.}

82. That is, SGT('white ${ }_{1}$ with-respect-to a-part-of-surface) $=\operatorname{SGT}$ ('white ${ }_{2}$ ') $\neq$ SGT ('white ${ }_{1}$ ) $=$ SGT ('white ${ }_{1}$ with-respect-to whole-surface'). Here 'white ${ }_{1}$ ' indicates the strict usage of 'white', in which it is true only of those things that are totally white, whereas 'white ${ }_{2}$ ' indicates a broader, less stringent usage of 'white', say, in which the white pages of the phone book can be called 'white' (as opposed to the yellow pages), despite the black letters that cover a part of their surface. Of course, in a complete semantics the hyphenated qualifications could (and should) be analyzed further, but that is irrelevant here. 
can be added or dropped without affecting the truth conditions of the predication. It follows from this that an inference secundum quid ad simpliciter that drops this qualification from 'white' will be valid. (It should be noted, however, that a qualification that is nondiminishing of one predicate may be diminishing of another; for example, 'with respect to its whole surface', is a diminishing qualification of 'hot', for something can be called strictly and properly hot only if it is hot in its every part, not only on its surface.) However, in ordinary usage we do not always bother adding even diminishing qualifications. Instead, we apply the same term without qualification, intending it to have some qualification which should be clear from the actual context. ${ }^{83}$ If such a usage is quite clearly related to the primary usage and is generally received, we get exactly an analogical, extended usage of the same term-that is, a usage of the term in which it applies to things to which it would not apply in this strict primary usage-but because of the implied qualification that relates it to its primary usage, it is still properly applicable in this secondary usage even without explicitly adding the relevant qualification. This, then, is the reason St. Thomas said that a division of a common term with respect to its analogata-that is, distinguishing a term's usage in its primary sense from its usage in its secondary, analogical senses-yields a distinction between the sense in which the term can be predicated simpliciter, and several other senses in which it can be predicated only secundum quid. ${ }^{84}$ Also, this is how, according to St. Thomas, 'being' is predicated simpliciter, in its primary sense, of substance (that is, of that which is simpliciter, a sub-

83. Indeed, most things we normally call white, even if they are white all over their whole surface, could not be called absolutely and totally white in the strictest sense; namely, in the sense in which the definition of whiteness would be satisfied absolutely and 100 percent by the property of the thing called white. On the basis of contemporary physical optics we could reasonably define that property, whiteness, as the reflective capacity of a surface measurable by what is called albedo (Latin for whiteness) in modern science, that is, the percentage of the reflected light relative to the incident light (which is, by the way, just one of the nicest illustrations, pace Molière, of modern science's unabashed usage of "scholastic barbarisms" when they come in handy). But then we can also quite reasonably say that only that thing can be called absolutely white that has 100 percent albedo. So any object with a lesser albedo is only white to a certain degree but not strictly and absolutely white, without any qualification, even if we normally would not add any qualification in ordinary usage. This example also shows very nicely that it is precisely this phenomenon, namely, the omission of several sorts of implied qualifications, that accounts for much of the vagueness or fuzziness of everyday usage, represented in contemporary "fuzzy logics" by assigning fuzzy or diminished truth values to predications, that is, truth values between (and including) 0 and 1 , instead of the classical 0 and 1 . However, in treating this fuzziness, instead of assigning fuzzy, qualified truth to unqualified, absolute predicates, medieval Aristotelian logicians assigned absolute, unqualified truth to either explicitly or implicitly qualified, fuzzy predicates. But vagueness is an issue beyond the scope of this paper.

84. See n. 14. 
sistent being), ${ }^{85}$ and secundum quid, in one of its secondary senses, of substantial forms (that is, of beings by which a substance is), accidents (that is, of beings by which a substance is somehow), beings of reason, beings in potentiality, and perhaps even mere objects of thought. ${ }^{86}$

It should also be clear, then, why St. Thomas would claim that there is a distinction between the attribution of being to something as to that which is and the attribution of being to something as to that by which something else (namely, a substance) is, even if in both cases we are talking about real beings and not about mere beings of reason. ${ }^{87}$ As was pointed out above, the act of being signified by ' $\mathrm{is}_{\mathrm{x}}$ ' in (ii) in (EP) is the very same act of being as that signified by the qualified predication of being in (iii). But if in (EP) for $\mathrm{P}$ we substitute an accidental predicate, 'is ${ }_{\mathrm{x}}$ ' will be true of the supposita of [P] only in a qualified sense, namely, in the same sense which is expressed by the qualified predication of being in (iii), but not in the primary sense, signifying the subsistence of a substance. The latter would be expressed by an unqualified predication of being in (iii). 88

But if it is only the absolute predication of 'is' of a substance that can express the primary sense of being, it might appear that ' $\mathrm{i}_{\mathrm{x}}$ ' in (ii), insofar as it is true, can never be 'is ${ }_{1}$ '; that is, it cannot express the primary sense of being for any substitution of $\mathrm{P}$, whether $\mathrm{P}$ is an accidental or a substantial predicate. For the subject term of (ii) supposits for the significata of $\mathrm{P}$ in the supposita of $\mathrm{S}$ by means of the abstract counterpart of $\mathrm{P}$, namely $[\mathrm{P}]$. However, according to St. Thomas, those that are signified in abstracto are signified as something by which something else is, not as that which is. ${ }^{89}$ However, it is only that which is by itself, namely, what subsists (a per se existing substance) that is said to be in the primary sense. So even if the act of being signified by ' $i s_{x}$ ' in the significatum of a substantial predicate of a substance is the same act of being that is signified by ' $\mathrm{is}_{1}$ ' in the same substance, ' $i \mathrm{~s}_{\mathrm{x}}$ ' cannot be the same as ' $\mathrm{is}_{1}$ '. Indeed, St. Thomas includes even substantial forms, that is, the significata of substantial predicates, among the things that can be said to be only in the qualified sense, as that by which something is. But since every predicate that signifies some real being is either substantial or accidental, it seems that nothing that is signified in abstracto can be said to be in the primary sense. Hence, for no substitution of $\mathrm{P}$ would 'is ${ }_{\mathrm{x}}$ ' in (ii) be 'is 1 ', that is, 'is' signifying the primary sense of being, insofar as (ii) is true.

85. "Non enim ens dicitur proprie et per se, nisi de substantia, cuius est subsistere. Accidentia enim non dicuntur entia quasi ipsa sint, sed inquantum eis subest aliquid, ut postea dicetur" (In De hebd lc. 2).

86. Cf. In meta. lb. 4, lc.1, n. 15.

87. See $Q D L 9$, q. 2, a. 2, in corp., quoted above.

88. Cf. In meta. lb. 7, lc. 1, n. 1256, quoted above.

89. 1 SN d. 33, q. 1, a. 2, in corp. Cf. In meta. lb.7, lc. 1, nn. 1252-1256. 
But St. Thomas would say that this reasoning confuses modi significandi with modi essendi, that is, confuses semantic with ontological distinctions. ${ }^{90}$ Although it is true that abstract terms are imposed to refer to what concrete terms signify, and in the case of material beings what are thus signified are inherent forms of material substances-for which to be is only for them to inform the matter of these substances (that is, to render these material substances actual in some respect) - this does not exclude the possibility of there being forms for which to be is not for them to make something else actual in some respect, but just to be, absolutely, in actuality. In the case of such a subsistent form, therefore, there is no real distinction between what is supposited for by the concrete and by the abstract term. Thus, 'is' or 'exists' or 'being' can equally and truly be predicated of both in the same, primary sense of being, that is, signifying the subsistence of a substance. ${ }^{91}$ Thus, whereas the semantic distinction (the difference between the mode of signification of an abstract term and that of a concrete term) is in force even concerning such an immaterial form, ${ }^{92}$ the lack of a corresponding ontological, or real, distinction is expressed precisely both by the fact that the abstract and concrete terms that signify and supposit for such a subsistent form are truly predicable of each other and by the fact that existence can be attributed to the thing thus signified and supposited for in the primary sense, whether the thing is referred to in concreto or in abstracto. ${ }^{93}$

Indeed, this also shows why, adapting D. P. Henry's happy phrase, the "aloofness" of Aquinas's semantic theory from ontology is so important, not only from the point of view of its acceptability by others of a different metaphysical persuasion, but also from the point of view of his own metaphysics. ${ }^{94}$ It is precisely this "aloofness" of the semantic theory, not prescribing anything concerning the ontological categories of the semantic values of our phrases, that makes it possible for Aquinas to admit subsistent forms into his ontology, that is, forms which exist not only as

90. For St. Thomas's principled insistence on keeping the two apart, see both his numerous discussions of what he took to be Plato's fundamental error concerning universals and of how the modi significandi of the names we attribute to God do not correspond to some matching modi essendi in Him.

91. $3 S N$ ds. 11, q. 1, a. 4; $S T 1$ q. 13, a. 1, ad 2-um. Cf. $S T 1$ q. 32, a. 2.

92. $Q D P$ q. 8, a. 3. Cf. $1 S N$ d. 22, q. 1, a. 2.

93. Cf. $S c G$ lb. 1, c. $30 ; 1 S N$ d. 22, q. 1, a. 2; De ente c. 5. See also n. 41.

94. For D. P. Henry's own Principle of Logical Aloofness, see That Most Subtle Question-(Quaestio Subtilissima): The Metaphysical Bearing of Medieval and Contemporary Linguistic Disciplines (Manchester: Manchester University Press, 1984). (See entry "aloofness" in the index.) Again, we should note here that the question of whether there are such subsistent forms or not is a metaphysical question, not determined by these semantic considerations. All these semantic considerations determine is what it means to claim that there are such subsistent forms. But, of course, it is only on the basis of the proper understanding of this claim that one can set about determining its truth. 
something by which something else (namely, a substance) is but also as that which is.

Thus, on the other hand, if in the scheme above we substitute 'God' for P (and also, for the sake of simplicity, for S) and if we take 'divinity' (or 'godhead', if you prefer a Saxon word in the abstract form) as the abstract counterpart of 'God', then we get the following:

$\left(\mathrm{E}_{1} \mathrm{P}\right)(\mathrm{i}) \mathrm{God}$ is $\mathrm{s}_{2}$ God iff (ii) God's divinity is $\mathrm{s}_{1}$ iff (iii) God is ${ }_{1}$ with respect to divinity

On the other hand, if we substitute, say, 'tree' for $\mathrm{P}$ (and, again, for S, too) and ' $i_{[1]}$ ' for ' $i s_{x}$ ' to distinguish the sense in which 'is' can be truly predicated of nonsubsistent substantial forms, and if we baptize the significata of 'tree' in individual trees 'arboreity' (or 'treeness', if you prefer), then we get

$\left(\mathrm{E}_{[1]} \mathrm{P}\right)(\mathrm{i})$ A tree is $\mathrm{s}_{2}$ a tree iff (ii) A tree's arboreity is ${ }_{[1]}$ iff (iii) $\mathrm{A}$ tree is ${ }_{1}$ with respect to arboreity

The point of the comparison is that even if we suppose that 'tree' is a substantial predicate of trees as 'God' is of God, if the form signified by 'tree' in trees (that is, the substantial form of trees) is not a subsistent form, then (ii) can be true only in a diminished, qualified sense, even if for a tree to be, absolutely and in the primary sense, is nothing but to have this substantial form in actuality (that is, to be in actuality with respect to that form). Nevertheless, it is only the substance that has this actuality as that which is (quod est), while the form, if it is not a substance itself, exists only insofar as that by which the substance of which it is the form has being (quo aliquid est), even if the form's act of being (provided the form is a substantial form) is the very same act of being that the substance itself has. ${ }^{95}$ However, should it turn out that arboreity, the substantial form of trees, is not only an inherent form but also a substance that for some reason should be regarded as having subsistent being, this would mean that, instead of (ii) in $\left(\mathrm{E}_{[1]} \mathrm{P}\right)$, 'A tree's arboreity is ${ }_{1}$ ' would be true. In fact, showing that the rational soul is precisely such a substantial form because of the fact that it has an operation that is not the actuality of the body is the most crucial step in Aquinas's proof of the immortality of the

95. Formally, the point is that if $P$ is a substantial predicate of a substance $u$,

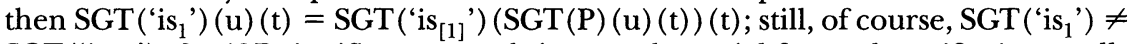
SGT ('is ${ }_{[1]}$ '), for if $P$ signifies a nonsubsistent substantial form, then, if $u$ is actually $P$ (i.e., SGT $(P)(u)(t) \in A(t))$, then $\operatorname{SGT}\left({ }^{\prime} i_{i 1}{ }_{[1]}^{\prime}\right)(\operatorname{SGT}(P)(u)(t))(t) \in A(t)$; nevertheless, SGT('is ${ }_{1}$ ') $(\operatorname{SGT}(\mathrm{P})(\mathrm{u})(\mathrm{t}))(\mathrm{t})=0$, and also $\operatorname{SGT}\left({ }^{\prime} \mathrm{is}_{[1]}{ }^{\prime}\right)(\mathrm{u})(\mathrm{t})=0$. For the general definition of what it is for a predicate $\mathrm{P}$ to be substantial to an individual substance u, see n. 98 below. 
human soul. 96 But again, from our present, semantic point of view, the important point is that whether this claim is true or false is not determined by the semantic theory itself, whereas it is these semantic considerations that tell us what such a claim means and so what evidence can be regarded as counting for or against it.

In any case, these comparisons between the various senses in which being may be attributed to different kinds of things should also show that it is precisely these different senses of being, once carefully distinguished, that can be used to express the basic ontological differences between various kinds of beings. Accidents are the kind of beings for which to be is to make substances actual in some respect, that is, for which to be is for their subject to be actual in some respect-actual by an act of being that does not make them actually be, simpliciter. So the act of being truly attributable to an accident is just an act of being secundum quid of the substance whose accident it is. Thus, the sense in which accidents can be said to be is only a sense of being secundum quid, analogically related to the primary sense, in which something is called a being simpliciter. Again, substantial forms are the kind of beings for which to be is to make a substance actual in respect of what it is. Hence, the act of being of a substantial form is the act of being of the substance itself. This is why the actuality of the substantial form makes the substance actual simpliciter and not only secundum quid. Still, unless the substantial form is itself a substance, either being the whole substance itself or being a substantial part of a composite substance, this act of being cannot be attributed to it as to that which is but only as to that by which the substance is. Finally, it is only substances that can be said to be absolutely and without qualification, in the primary sense of being.

In these comparisons we have already seen that even among substances there are important differences with respect to their being. Even if all sorts

96. Cf. $Q D A$ q. 14. Indeed, this is precisely the point that Siger of Brabant, unable to separate modi essendi from modi significandi in the way Thomas did, found unacceptable in Thomas's conception of the intellective soul:

Praeterea, alia est ratio essendi formae materialis et compositi seu formae per se subsistentis. Ratio enim essendi formae materialis est secundum quam est aliquid aliud, ut ratio compositionis est secundum quam habet esse compositum, et ratio figurae secundum quam habet esse figuratum unde ratio essendi formae materialis est quod sit unita alii. Ratio autem essendi compositi vel formae liberatae a materia est quod sit ens per se et separate, non unum ens cum alio. . . Et sunt istae rationes essendi, qua aliquid habet esse unite ad materiam et qua aliquid habet rationem subsistentis per se et separate, oppositae adeo ut eidem inesse non possunt. Unde anima intellectiva non potest habere rationem per se subsistentis et, cum hoc, unum facere cum materia et corpore in essendo.

Siger of Brabant, De anima intellectiva, in B. Bazán, Siger de Brabant (Paris: Louvain, 1972), pp. 79-80. Cf. also St. Thomas's De unitate intellectus, nn. 37-38. 
of substances can be said to be without qualification, in the primary sense of being, we could also see that the being of these various sorts of substances was at the same time the being of their substantial forms, which, insofar as they make them be what they are, are what distinguish these various sorts from each other, determining their specific and generic kinds. Since their actuality simpliciter is nothing but their actuality in respect of their substantial form, their being, too, is determined to that form: ${ }^{97}$ they can only be actual inasmuch as their form permits them to be, for this (namely, to be in respect of their substantial forms) is precisely what it is for them just to be, simpliciter. But then these determinations of being in the determinate kinds of substances are also limitations on the actuality in principle available to a substance of a given, determinate kind. And if this is true, then different determinations yield different limitations, which in turn imply different degrees.

It is in this way, then, that from the analysis of the various analogical senses of being in their relation to the primary sense, in which it is predicable of substance, we can arrive at an idea of the different degrees of being that is not only comprehensible but even plausible, even for different kinds of substances themselves. (It makes no difference whether we are actually able to correctly identify-let alone measure-these various degrees.) In any case, the semantic question, again, is not whether what is said in particular in arranging different kinds of substances according to different degrees of being is true (that is, whether humans, say, are indeed a higher form of being than worms, for example), for that is a question of metaphysics; the semantic question is whether what is thus said makes good sense, and if so, then what sense it makes. This has to be understood before we inquire into truth, under pain of ignoratio elenchi.

\section{THE GREAT CHAIN OF BEING}

We have seen how the different analogous senses of being are all related to the primary sense (signifying the subsistence of a substance), namely, how these secondary senses are interpretable, in the framework of the inherence theory of predication and the corresponding theories of signification and supposition, as signifying being in some qualified sense that derives from the primary sense by the addition of some diminishing qualification. However, we have also seen that even within the range of application of this primary sense of being it is possible to distinguish different degrees of being, insofar as different kinds of substances are different precisely because of their different substantial forms. These substantial forms may be regarded in turn as just further (not properly diminishing but in a certain 
way limiting) qualifications on some more central, more absolute sense of being. These limiting qualifications yield differences that we may characterize as constituting different degrees of being.

Let us take a closer look at this idea, and let us see how we can say that, despite the fact that the actuality of a substantial form is an act of being attributable to the substance that has this form in the primary, absolute sense, the form itself imposes some limitation on this absolute being, determining it to a certain degree in comparison to others. Our starting point, again, should be a comparison of the various instances of the scheme (EP):

(EP) (i) An $\mathrm{S}$ is ${ }_{2} \mathrm{P}$ iff (ii) An S's [P] is $\mathrm{x}_{\mathrm{x}}$ iff (iii) An $\mathrm{S}$ is ${ }_{1}$ with respect to $[\mathrm{P}]$

We have seen that the act of being signified by the qualified predicate in (iii) is the same act of being as that signified by ' is $_{\mathrm{x}}$ ' in (ii). We have also seen that if the subject term (i.e., the phrase S's [P]) of (ii) supposits for an inherent, as opposed to a subsistent, form, then 'is ${ }_{\mathrm{x}}$ ' can be truly predicated of it only if it is not 'is ${ }_{1}$ '. In this case, being can be attributed to the form supposited for by this term only as to that by which something else [namely, the substance supposited for by $\mathrm{S}$ in (iii)] is and not as to that which is. However, if $P$ is a substantial predicate, then the act of being signified by 'is $\mathrm{x}^{\text {' }}$ in (ii) is the very same act as that by which the substance itself is, absolutely and in the primary sense, for this is precisely what it is for $\mathrm{P}$ to be a substantial predicate of the supposita of S. ${ }^{98}$ Therefore, provided P is a substantial predicate of the supposita of $\mathrm{S}$, we can supplement (EP) as follows:

(EP*) (i) An $\mathrm{S}$ is ${ }_{2} \mathrm{P}$ iff (ii) An S's [P] is ${ }_{x}$ iff (iii) An $\mathrm{S}$ is ${ }_{1}$ with respect to $[P]$ iff (iv) An $S$ is 1

since the act of being signified by the predicate of (ii) is the same as the act of being signified by the predicate of (iii), which in turn is the same act of being signified by 'is ${ }_{1}$ ' as an absolute predicate of $S$ in (iv), we can see that even the absolute predication of 'is ${ }_{1}$ ' in (iv) involves an implied determination or qualification, namely, the qualification of being provided by the substantial form signified by $\mathrm{P}$ in the supposita of $\mathrm{S}$. So if the predication of 'is ${ }_{1}$ ' in (iv) is true at all, it can be true only in the sense in which the predication of 'is ${ }_{1}$ with respect to $[\mathrm{P}]$ ' is true in (iii). ${ }^{99}$ This means that an $\mathrm{S}$ can be only in the way things that have the substantial form signified by $\mathrm{P}$

98. For, in general, a predicate $P$ is substantial to a substance $u$ iff $\operatorname{SGT}\left(\right.$ 'is ${ }_{\mathrm{x}}$ ') $(\operatorname{SGT}(\mathrm{P})(\mathrm{u})(\mathrm{t}))(\mathrm{t})=\operatorname{SGT}\left({ }^{\prime} \mathrm{is}_{1}{ }^{\prime}\right)(\mathrm{u})(\mathrm{t})$; otherwise $\mathrm{P}$ is accidental to $\mathrm{u}$. Cf. n. 95 .

99. That is, if $P$ is a substantial predicate of $u$, then $\operatorname{SGT}\left(\right.$ 'is $\left._{1}{ }^{\prime}\right)(u)(t)=\operatorname{SGT}$ ( ${ }^{\text {is }}{ }_{1}$ with-respect-to $\left.[\mathrm{P}]^{\prime}\right)(\mathrm{u})(\mathrm{t})$. 
can be, but not in any other way. What is, say, a diamond (provided 'diamond' is a substantial predicate of diamonds) can be only in the way a diamond can be, localized in space and time and characterized by certain capacities and incapacities, such as being capable of scratching other solid bodies, but, say, not being capable of self-propagation. In contrast, what is a tree (provided 'tree' is a substantial predicate of trees) can be only in the way trees are-also localized in space and time but characterized by different capacities and incapacities, and so on.

It seems, then, that whatever substantial predicate we substitute for $\mathrm{P}$ in the above scheme, the substantial form signified by that predicate will always impose some determination and thereby a certain limitation on the act of being signified by 'is ${ }_{1}$ ' in (iv). However, what if we can find a predicate that signifies a substantial form which, not being distinct from this act of being itself, does not impose any determination or limitation on the kind of being signified by 'is' 1 ' in (iv)? Suppose we find such a predicate, and we find that there is a being whose substantial form signified by this predicate is the very act of being that is signified in it by the predicate 'is 1 '. ${ }^{100}$ Such an act of being then would truly be called infinite, in the sense of not being determined to the capacity of some form distinct from it. Therefore it is only an entity that has such an act of being that could be said truly and genuinely absolutely to be, without any restriction or limitation (whether explicit or implicit) imposed on what is signified in it by the verb 'is' or by the predicate 'being'. It is only to such an entity that these terms would most properly, absolutely, and maximally apply, without any limitation of a particular kind or degree. Aquinas's metaphysical proofs are designed to show precisely that there is such an entity, God, because God's nature, the "form" signified by the term 'God', is identical to the act of being sigified by the term 'being' in Him. But then this is why Aquinas can claim that 'He Who Is' (qui est) is the most proper name of God, expressing most clearly the unlimited character of Divine Being, and that even among substances, which all are beings in the primary sense, it is God to whom this term most properly and maximally applies. ${ }^{101}$

But such a being, the nature of which is nothing but its act of being, can be only one, for there could be two such beings only if the one would be different from the other. Therefore, one of them would have to have something, some form, that somehow qualifies and thereby restricts its being. But then the nature of that being would not be the pure, unlimited, unqualified act of being, so that other being would not be the kind of being of which we assumed that we had two. ${ }^{102}$ Different kinds of beings, which are different because of their different forms, have their acts of being qualified and limited differently by their forms, and thus these acts of being

100. That is, suppose we find a $P$ such that for a substance $u, \operatorname{SGT}(P)(u)(t)=$ SGT('is $\left.{ }_{1}^{\prime}\right)(\mathrm{u})(\mathrm{t})$.

101. ST1 q. 13, a. 11.

102. In De hebd lc. 2, n. 33. ScG 1b. 1, c. 42, n. 10. 
are either more or less removed from the fullness of absolute being, thereby constituting different degrees of being. 103

However, even this overall hierarchy of being that is necessarily generated by the different substantial forms of different kinds of substances (which are different precisely because they are nothing but more or less restrictive qualifications of the absolute, unqualified being ${ }^{104}$ ) allows for further, even finer degrees of being, on the level of individuals, in which the same substantial nature may be more or less perfectly realized in the actualization of the individuals' accidents.

How should we understand this claim? What does the accidental being of a substance's accidents have to do with the degree of the substantial being of the substance itself? Even granting that different kinds of substances can be arranged into a hierarchy with regard to the perfection of their substantial being (even if we may not be able to determine the exact position of any given kind in this hierarchy), is it not the case that any given individual of any given kind either simply is or simply is not, at the degree determined by its kind?

The answer to this last question, as one may expect, is yes, absolutely speaking, but no with qualification. Absolutely speaking, any substance of any given kind either is or is not, but if it is at all, absolutely speaking, it can still be more or less; that is, it can still be or not be with some qualification (it can still be to a certain extent or not be to that extent). But again, is this not just play with words? If a substance already is by its substantial being, it may or may not have several sorts of accidental being. But why would the actuality or nonactuality of any such accidental being have anything to do with the degree or intensity of its substantial being?

To this we can say, first, that we must not forget that even if an accidental act of being of a substance is not identified with its substantial act of being, that accidental act is a certain act of the substance itself, an act of being secundum quid, because of which it is the substance that is in actuality in some respect. Indeed, it is only such actualities secundum quid that manifest the degree of a given substantial being in the first place in the overall hierarchy of beings determined by the substantial form of the kind of the substance in question. The degree of a given sort of substantial being determines, and thereby manifests itself precisely in, the range of actualities that are in principle available to or attainable by any particular substance that holds that degree of substantial being by belonging to its kind, that is, that has the kind of substantial form that determines that degree of substantial being. For example, supposing with Aquinas that living is a sort of substantial being that is of a higher degree than sheer

103. $S c G$ lb. 3 , c. 97 , n. 3 .

104. For this point see J. F. Wippel, "Thomas Aquinas and Participation," in Studies in Medieval Philosophy, ed. J. F. Wippel (Washington, D.C.: The Catholic University of America Press, 1987). 
lifeless existence, ${ }^{105}$ we can say that this is so because the notion of the mode of being which is living imposes less limitation on the notion of absolutely unqualified being than does the notion of a lifeless existence (perhaps it imposes no restriction at all). 106 This manifests itself precisely in the fact that the actualities in principle available to or attainable by a living being are in principle unavailable to or unattainable by a lifeless being, just because of the difference between what it is for something to live and what it is for something merely to be but not to live.

But is there still not some problem here? Even granting that a living being can do things that a lifeless being cannot, which may be regarded as the manifestation of a higher degree of substantial being, is not the converse also possible, indeed, actually true, namely, that a lifeless being can do things that a living being cannot? And if so, is not this latter capacity a manifestation of a higher degree of substantial being as well? In that case do we not have to conclude that the same lifeless being has a higher degree of substantial being than the living being, in contradiction to what we just conceded?

Of course, it is true that lifeless things can do several things that living things cannot do; a diamond, for example, can scratch glass, which a tree or a cat cannot do. (In fact, properly speaking, a diamond cannot scratch glass by its own activity either, but this is beside the point. The point is that the body of a tree or a cat lacks the capacity that a diamond has, namely, to scratch glass when it is rubbed against it, even if this requires the action of an external force.) But we should realize that the mere difference in the range of available capacities does not automatically translate into differences in the degree of substantial being. If a capacity is available precisely because of the unavailability of some other capacity or a whole range of other capacities, which in its turn is directly an indication of a higher degree of substantial being, then the availability of the former is an indication not of a higher but of a lesser degree of substantial being. This is the case in the example: a diamond has the capacity to scratch glass precisely because it has the sort of molecular structure that prevents it from performing all sorts of activities in which the degree of being we call life manifests itself. Hence, this capacity is precisely an indication of a more limited form of being. 107

From our present point of view such an example, or any other particular case, is relevant only to the extent it helps illustrate how the general

105. Whether this is indeed so is a metaphysical question, again left undetermined by our formal, semantic considerations, but for the sake of the example it is a quite plausible assumption in any case.

106. Cf., for example, $S T 1$ q. 18, a. 3; $S c G$ lb. 1, cc. 97-98.

107. Note that in this argument, we already assumed with Aquinas that life is a kind of being of a higher degree than lifeless existence. This argument shows only that the fact that lifeless entities can have certain capacities that living beings do not have does not contradict this assumption. Of course, it is a further issue whether and why we are justified in this assumption. For this see Aquinas's texts referred to in n. 106. 
semantic principles concerning the concept of being should be applied in the particular discussions of these particular cases. ${ }^{108}$ These principles themselves, however, being presupposed by the discussion of particular cases, should be regarded as valid regardless of the outcome of any particular discussion, provided they are consistent in themselves and with one another.

108. Consider the following, more drastic example. God cannot scratch His nose. This is not an incapacity, absolutely speaking, for this is an incapacity only insofar as a higher capacity excludes the presence of the limiting opposite capacity. My capacity to scratch my nose is a capacity that directly involves the limitation on the form of being I have, namely, the limitation that it is a sort of bodily existence, restricted to a portion (a rather small portion at that!) of space and time. So I can have this particular, limited capacity only and precisely on account of the obviously restricted mode of being I have. Thus, despite possible appearances to the contrary, this capacity is obviously an indication of a lower degree of being, whence the lack of this capacity in, or rather its sheer inapplicability to, Divine Being is just a further indication of the absolute perfection of that Being. See Thomas on why we cannot truly and properly predicate of God terms that signify perfections but also necessarily involve limitations of being. Cf. $S T 1$ q. 13, a. 3; $1 S N$ d. 22, q. 1, a. 2. 


\section{New in Medferal studfes}

\section{The Wife of Bath's Prologue on CD-ROM \\ Geoffrey Chaucer \\ Peter Robinson, Editor}

This CD-ROM is the initial release in the

Canterbury Tales Project from Cambridge. It presents transcriptions, collations and digitized images of all fifty-eight pre-1500 manuscript and print versions of Geoffrey Chaucer's famous poem. Software allows sophisticated searches of all the manuscripts simultaneously.
46593-1
CD-ROM
$\$ 240.00$

\section{Monks and Laymen in Byzantium,$$
\text { 843-1118 }
$$ \\ Rosemary Morris}

This book reassesses the role of monks in

Byzantine society and examines the reasons for the flowering of the monastic life in the period from the end of iconoclasm to the beginning of the twelfth century.

26558-4 Hardback \$64.95

\section{Christendom and its Discontents}

Exclusion, Persecution, and Rebellion, 1000-1500

\section{Scott L. Waugh and}

Peter Diehl, Editors

This book of essays examines the sources of dissent and diversity in medieval society and

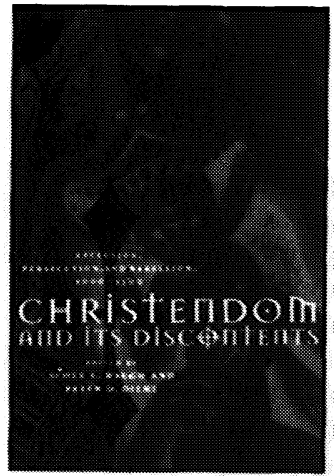
the Church's attempt to repress dissent and enforce conformity to its beliefs between the years 1000 and 1500 .

Contributors: R.I. Moore, Peter Diehl, James Given, Mary A. Rouse, Richard H. Rouse, Clifford R. Backman Anne Hudson, Anne L. Clark, E. Ann Matter, Katherine Gill, Carlo

Ginzburg, Robert Chazan, David Abulafia, Olivia Remie Constable, Gavin I. Langmuir, Richard Kieckhefer, Edward M. Peters 47183-4 Hardback
The Reluctant Emperor

A Biography of John Cantacuzene, Byzantine Emperor and Monk, C. 1295-1383

Donald M. Nicol

This is the first biography of John Cantacuzene in English.

55256-7 Hardback \$39.95

\section{Medieval Isma'ili History and Thought \\ Farhad Daftary, Editor}

This collection of essays brings together some of the original results of modern Isma'ili scholarship. The contributions deal with important historical and doctrinal issues, as well as the specific literary and intellectual traditions.

Contributors: F. Daftary, Wilferd Madelung, Heinz Halm, Ismail K. Poonawala, Abbas Hamdani, Azim Nanji, Paul E. Walker, Carole Hillenbrand, C. Edmund Bosworth, Hamid Dabashi, Charles Melville, Ali S. Asani, Abbas Amanat

45140-X Hardback \$59.95

\section{Religion and Devotion in Europe, c. 1215 - C. 1515 R.N. Swanson} Avoiding the history of institutional structures, the book concentrates on the spirituality that

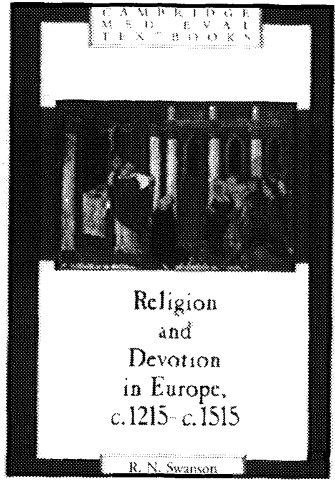
the medieval

Church sought to promulgate and control.

Cambridge Medieval Textbooks

37076-0 Hardback $\$ 69.95$

37950-4 Paperback \$18.95

\section{The Papacy, Scotland and} Northern England, 1342-1378 A.D.M. Barrell

This is the first analysis of the full breadth of papal involvement in late medieval Britain, using local sources in conjunction with material from the Vatican Archives.

Cambridge Studies in Medieval Life and Thought: Fourth Series 30

44182-X Hardback \$5995 


\section{Wew in Medferal studfes}

\section{The New Knighthood}

A History of the Order of the Temple

\section{Malcolm Barber}

Malcolm Barber's lucid narrative separates myth from history in this full and detailed account of the Order, from its origins, flourishing and suppression to the Templars' historical afterlife. A Canto Book

55872-7 Paperback \$11.95

\section{The Darkness of God}

Negativity in Christian Mysticism

\section{Denys Turner}

For the medieval mystical traditions, the

Christian soul meets God in a "cloud of

unknowing," a divine darkness of ignorance.

Turner argues that the distinctiveness and contemporary relevance of medieval mysticism lies precisely in its rejection of "mystical experience." 45317-8 Hardback \$54.95

\section{Power, Gender and Christian Mysticism Grace M. Jantzen}

This book is the first on the subject to take issues of gender seriously, and to use them as a point of entry for a deconstructive approach to Christian mysticism.

Cambridge Studies in Ideology and Religion 8

47376-4 Hardback \$64.95

47926-6 Paperback $\$ 18.95$

\section{Cambridge Studies in} Anglo-Saxon England

\section{The Text of the Old}

\section{Testament in Anglo-Saxon}

\section{England}

Richard Marsden

This book is the first to describe the transmission of the Vulgate Old Testament in Anglo-

Saxon England. It illuminates important areas of monastic and intellectual life, and establishes textual history as a dimension of wider AngloSaxon history.

46477-3 Hardback $\$ 80.00$

Available in bookstores or from

The 'Laterculus Malalianus' and the School of Archbishop Theodore Jane Stevenson, Editor

This edition presents a translation of and commentary on the "Laterculus Malalianus" and examines the intellectual milieu of this work. 37461-8 Hardback \$59.95

Cambridge Texts in the History of Political Thought

\section{William of Ockham:}

\section{A Letter to the Friars Minor} and Other Writings

Arthur Stephen McGrade and John Kilcullen, Editors

35243-6 Hardback \$6495

35804-3 Paperback $\$ 24.95$

Now in paperback...

Nicholas of Cusa: The Catholic Concordance Paul E. Sigmund, Editor

56773-4 Paperback \$2495

\section{The Cambridge Companion to Aquinas \\ Norman Kretzmann and \\ Eleonore Stump, Editors \\ Cambridge}

Companions to

Philosophy

43769-5

Paperback

$\$ 19.95$

\section{St. Anselm}

A Portrait in a

Landscape

R.W. Southern

43818-7

Paperback

$\$ 24.95$

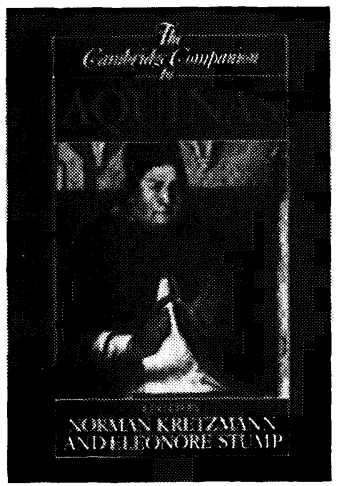

CAMBRIDGE UNIVERSITY PRESS
40 West 20th Street, New York, NY 10011-4211 Call toll-free 800-872-7423.

Web site: http://www.cup.org

MasterCard/VISA accepted. Prices subject to change. 
